\title{
How to decarbonise international shipping: options for fuels, technologies and policies
}

Paul Balcombe ${ }^{\left(a, b,{ }^{*}\right)}$, James Brierley ${ }^{(c)}$, Chester Lewis $^{(\mathrm{d})}$, Line Skatvedt ${ }^{(\mathrm{c})}$, Jamie Speirs ${ }^{(\mathrm{a}, e)}$, Adam Hawkes $^{(a, b)}$, lain Staffell ${ }^{(c)}$

(a) Sustainable Gas Institute, Imperial College London, London SW7 1NA, UK

(b) Department of Chemical Engineering, Imperial College London SW7 2AZ, UK

(c) Centre for Environmental Policy, Imperial College London, London SW71 NE, UK

(d) E4tech, 83 Victoria St, Westminster, London SW1H OHW, UK

(e) Department of Earth Science and Engineering, Imperial College London, SW7 2BP, UK

*Corresponding author: p.balcombe@imperial.ac.uk

\section{Abstract}

International shipping provides $80-90 \%$ of global trade, but strict environmental regulations around $\mathrm{NO}_{\mathrm{x}}, \mathrm{SO}_{\mathrm{x}}$ and greenhouse gas (GHG) emissions are set to cause major technological shifts. The pathway to achieving the international target of $50 \%$ GHG reduction by 2050 is unclear, but numerous promising options exist. This study provides a holistic assessment of these options and their combined potential to decarbonise international shipping, from a technology, environmental and policy perspective. Liquefied natural gas (LNG) is reaching mainstream and provides $20-30 \% \mathrm{CO}_{2}$ reductions whilst minimising $\mathrm{SO}_{\mathrm{x}}$ and other emissions. Costs are favourable, but GHG benefits are reduced by methane slip, which varies across engine types. Biofuels, hydrogen, nuclear and carbon capture and storage (CCS) could all decarbonise much further, but each faces significant barriers around their economics, resource potentials and public acceptability. Regarding efficiency measures, considerable fuel and GHG savings could be attained by slow-steaming, ship design changes and utilising renewable resources. There is clearly no single route and a multifaceted response is required for deep decarbonisation. The scale of this challenge is explored by estimating the combined decarbonisation potential of multiple options. Achieving $50 \%$ decarbonisation with LNG or electric propulsion would likely require 4 or more complementary efficiency measures to be applied simultaneously. Broadly, larger GHG reductions require stronger policy and may differentiate between short- and long-term approaches. With LNG being economically feasible and offering moderate environmental benefits, this may have short-term promise with minor policy intervention. Longer term, deeper decarbonisation will require strong financial incentives. Lowest-cost policy options should be fuel- or technology-agnostic, internationally applied and will require action now to ensure targets are met by 2050 . 


\section{Glossary}

$\begin{array}{ll}\text { BAU } & \text { Business as usual } \\ \text { ECA } & \text { Emission control area } \\ \text { EEDI } & \text { Energy Efficiency Design Index } \\ \text { EP } & \text { Electric Propulsion } \\ \text { ETS } & \text { Emission Trading Scheme } \\ \text { FOC } & \text { Flag of convenience } \\ \text { HFO } & \text { Heavy Fuel Oil } \\ \text { IGF Code } & \text { International Gas Fuelled Ship Code } \\ \text { IMO } & \text { International Maritime Organisation } \\ \text { IMS } & \text { International Maritime Services } \\ \text { IPPC } & \text { Integrated Pollution Prevention and Control } \\ \text { ITF } & \text { International Transport Workers' Federation } \\ \text { MARPOL } & \text { Maritime Agreement Regarding Oil Pollution } \\ \text { MBM } & \text { Market-based mechanism } \\ \text { MDO } & \text { Marine Diesel Oil } \\ \text { MEPC } & \text { Maritime Environment Protection Committee } \\ \text { METS } & \text { Maritime Emission Trading Scheme } \\ \text { MGO } & \text { Marine Gas Oil } \\ \text { RoRo } & \text { Roll on - Roll off Ship } \\ \text { SCR } & \text { Selective Catalytic Reduction } \\ \text { WHRS } & \text { Waste Heat Recovery Systems } \\ \text { WSC } & \text { World Shipping Council }\end{array}$




\section{Introduction}

Maritime shipping is a key component of the global economy representing $80-90 \%$ of international trade $[1,2]$. Sea transport emits less carbon dioxide per tonne-km compared to other forms of transport [3-5], but given its sheer scale, the maritime sector is a major contributor to global ecological impacts [6]. The shipping industry is responsible for emitting approximately $1.1 \mathrm{Gt}$ of carbon dioxide (3\% of global greenhouse gas emissions), as well as 2.3 Mt of sulphur dioxide and 3.2 Mt nitrogen oxides per year [7-9]. For context, if the maritime industry were a country, it would be the $6^{\text {th }}$ largest $\mathrm{CO}_{2}$ emitter worldwide (ahead of Brazil and Germany).

For this reason, the International Maritime Organisation (IMO) (the UN agency for shipping) has established a target for global shipping to decarbonise by at least $50 \%$ from 2008 levels by 2050 [10]. Similarly, Maersk (the world's largest shipping container company) has announced its intentions to be net-zero carbon by 2050, with carbon neutral vessels commercially viable by 2030 [2].

This environmental impacts of shipping are set to rise as world seaborne trade is anticipated to grow by around 3\% per year into the early 2020s [11]. Even ambitious decarbonisation scenarios see energy consumption growing by 40-50\% between 2015 and 2050 [12], whilst other sectors proceed with decarbonising rapidly. Maritime freight is responsible for $12 \%$ of global transport energy demand (see Figure 1), totalling approximately 13 million TJ in 2015, or $1.4 \mathrm{kWh}$ per person per day globally [13]. Consequently, the sector is placed in a unique position to not only contribute to climate change mitigation by directly reducing emissions, but also by becoming leaders in climate innovation and enabling the decarbonisation of other energy sectors via development of low carbon fuel infrastructure.

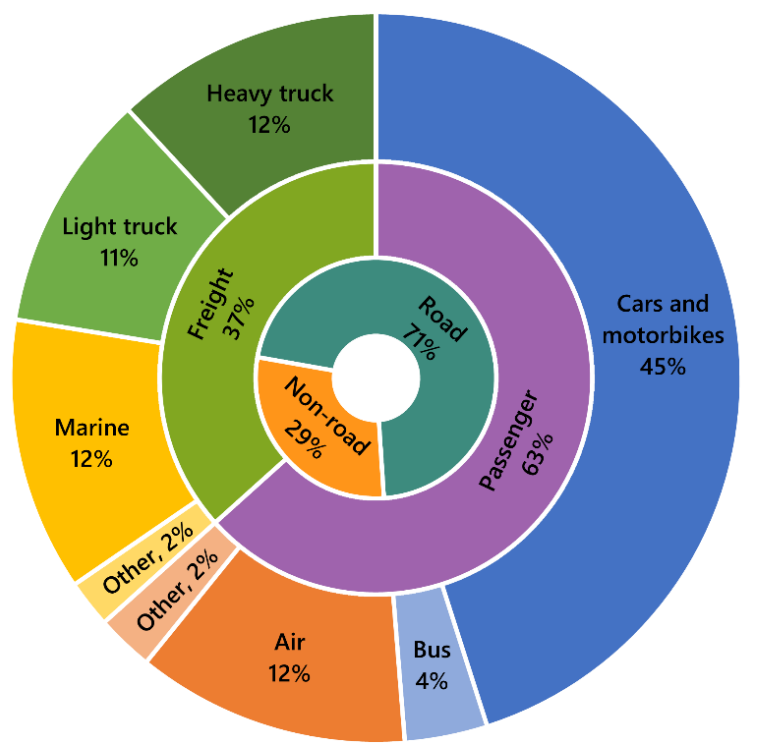


Figure 1: Breakdown of energy usage in the transport sector globally in 2015. The outer ring gives the share of individual modes, the middle and inner rings aggregate these uses. Data from [13].

However despite this, the sector has been largely unregulated until recently [6]. Stringent targets have been put in place to significantly reduce $\mathrm{NO}_{\mathrm{x}}$ and $\mathrm{SO}_{\mathrm{x}}$ air-quality-related emissions [15] and, crucially, in 2018 the IMO set a target for global shipping to decarbonise by at least $50 \%$ from 2008 levels by 2050 [10].

As with other sectors, there is no silver bullet solution to decarbonisation. It is likely that halving carbon emissions will require a range of options, including new fuel sources, raising technical or operational efficiencies and reducing demand. Shipping has undergone paradigm shifts in fuel before, from coal to diesel in the 1920s and from diesel to heavy fuel oil (HFO) in the 1950s [17]. Liquefied natural gas (LNG) is the main alternative fuel to liquid fossil fuels, offering reduced air quality impacts and direct $\mathrm{CO}_{2}$ emissions, although methane emissions have been shown to reduce the GHG benefit [18]. Other alternatives include biofuels, methanol, hydrogen, electric propulsion or even nuclear fuels, but each offer differing levels of decarbonisation and incur different economic costs as well as pollutants relating to air quality. Likewise, various efficiency measures exist that would reduce the fuel consumption per unit distance, particularly the act of slow steaming. But their impact on efficiency depends on various factors such as the class of vessel and its application.

This study reviews the different combinations of fuels, technologies and policies that may be used to reduce GHG emissions from international shipping. For each option, the emissions reduction potential is quantified and feasibility from a technical, economic and political perspective is assessed. Combinations of possible reduction measures are assessed and recommendations are made in terms of effectiveness and economic-political feasibility. The focus of this study is on commercial shipping, particularly with respect to international trade given the anticipated growth resulting from increasing population and economic development.

Existing literature has included broad estimates of global shipping decarbonisation routes $[3,19]$, as well as some specific estimates of emission reduction measures relating to energy efficiency or vessel design [3, 20, 21], or from alternative fuels $[22,23]$. In particular, Bouman et al. [20] summarise a large proportion of literature on the potential emissions reductions associated with energy efficiency, ship design and fuel changes. They suggest a combination of technologies would result in large reductions and that the knock-on impacts of other non- $\mathrm{CO}_{2}$ emissions (such as methane, $\mathrm{NO}$ and $\mathrm{SO}$ ) must also be considered. Yuan et al. [24] estimated global $\mathrm{CO}_{2}$ savings from a selection of energy efficiency measures under uncertainty, whilst a few studies estimate the cost-effectiveness and emissions- 
reduction potential of energy efficiency measures [25] and fuels for the global fleets [26]. Many studies also analyse the policy mechanisms that may achieve shipping decarbonisation such as market-based mechanisms (MBMs) and further efficiency improvement legislation [3, 27-29]. This review adds to this body of literature by providing an up-to-date assessment of the current status of shipping and emissions, investigating a broad selection of fuel, technical and operational emission reduction options, and providing a policy assessment to provide insight into how to achieve a $50 \%$ GHG emissions reduction target.

The contribution of this study is to inform pathways to achieve deep decarbonisation, to highlight the mechanisms with greatest potential to reduce emissions and to identify critical research gaps. In the next section, the current state of the maritime industry is outlined, with respect to fleets, fuels, emissions and current regulatory frameworks. Sections 3 and 4 quantify the potential impacts associated with different fuel switches, including liquefied natural gas (LNG, Section 3), renewables and nuclear options (Section 4). Section 5 evaluates the impact of various energy efficiency measures, before the policy mechanisms to achieve emissions reductions are assessed in terms of current status and future potential. The combined emissions reductions associated with different combinations of reduction measures are assessed in Section 7, before conclusions and recommendations for technical and regulatory change are made in Section 8.

\section{The current status of international shipping}

Globally there are around 52,000 merchant ships contributing to international shipping of goods and passengers (see Figure 2). For a sense of scale, these ships are propelled by over $500 \mathrm{GW}$ of engine capacity [30], more than Europe's entire fleet of fossil-fuelled power stations [31]. There is significant heterogeneity across the merchant fleet with different services, ships, fuels, emissions and regulations, thus there is no one-size-fits-all decarbonisation solution. The following describes current status of international shipping regarding emissions, fuel use and regulatory environments. 


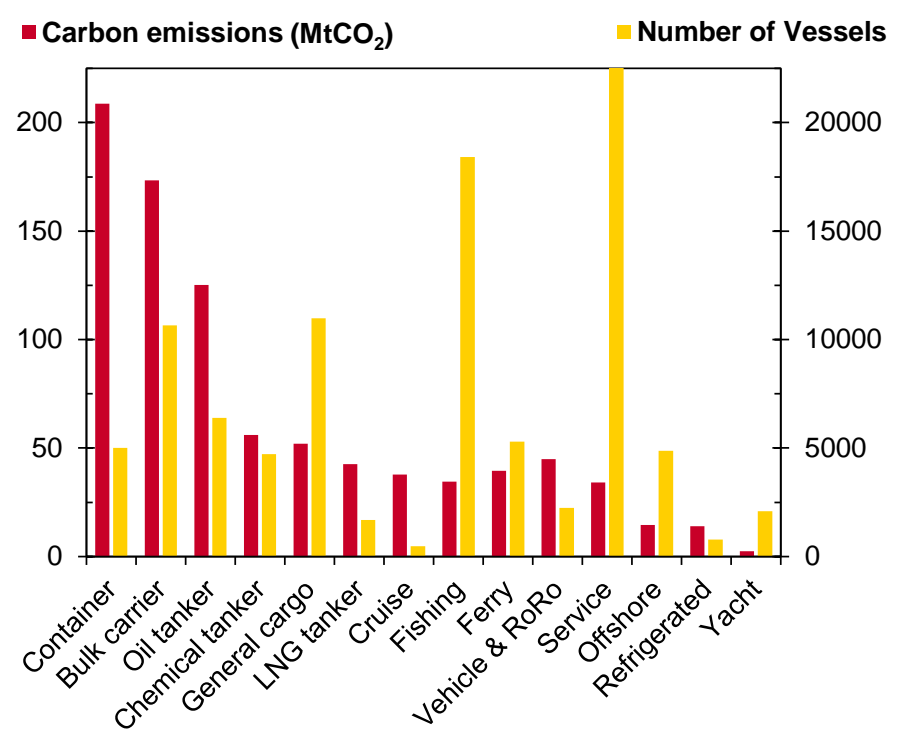

Figure 2. Number of merchant ships and their carbon emissions, by category in 2017.

Ferry includes passenger and passenger-RoRo (roll-on roll-off). Data from [30].

\subsection{Current Emissions from Shipping}

In 2014, international shipping emitted $1,130 \mathrm{Mt} \mathrm{CO}_{2}$, which accounts for $3.1 \%$ of global $\mathrm{CO}_{2}$ emissions [32]. As shown in Figure 3, shipping emissions have consistently increased since 1990, largely in line with global trade increases. However the contribution to total emissions has actually decreased from 2007 - 2014 , largely due to growth in other non-shipping emissions rather than decarbonised shipping, particularly growth in emissions from coalfired electricity generation in China and India [32].

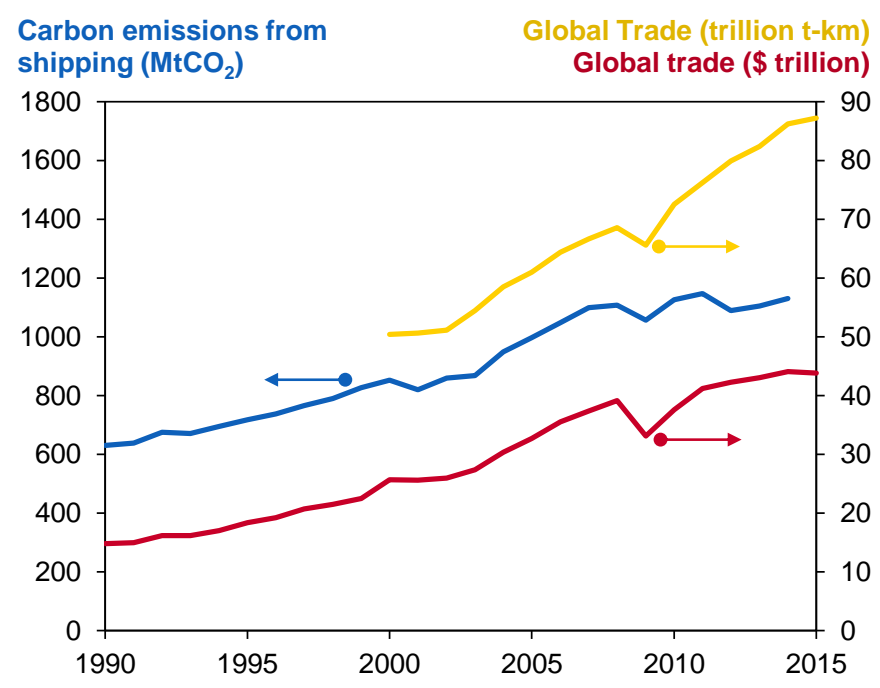




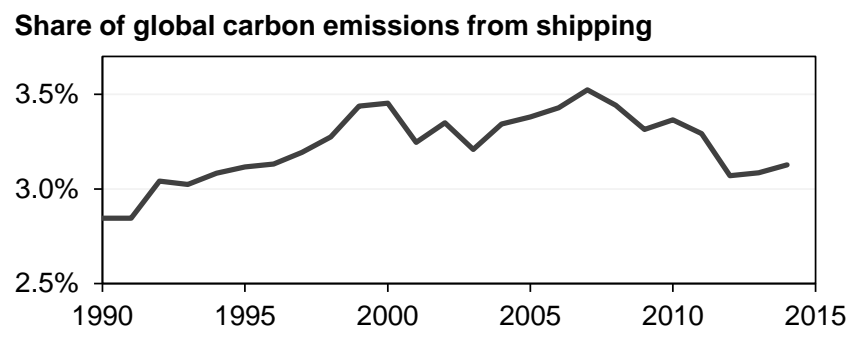

Figure 3: $\mathrm{CO}_{2}$ emissions from global shipping set against global trade (top panel); and the relative share of $\mathrm{CO}_{2}$ emissions that come from shipping (bottom panel). Data from $[3,9,32,33]$.

The greatest source of GHG emissions within shipping are from container ships, bulk carriers and oil tankers, as shown in Figure 2. This is due to these vessels conducting longer journeys to deliver their cargo - international and intercontinental, rather than domestic and coastline routes [32]. The spatial distribution of these emissions is shown in Figure 4, and covers most of the oceans and seas in the northern hemisphere.

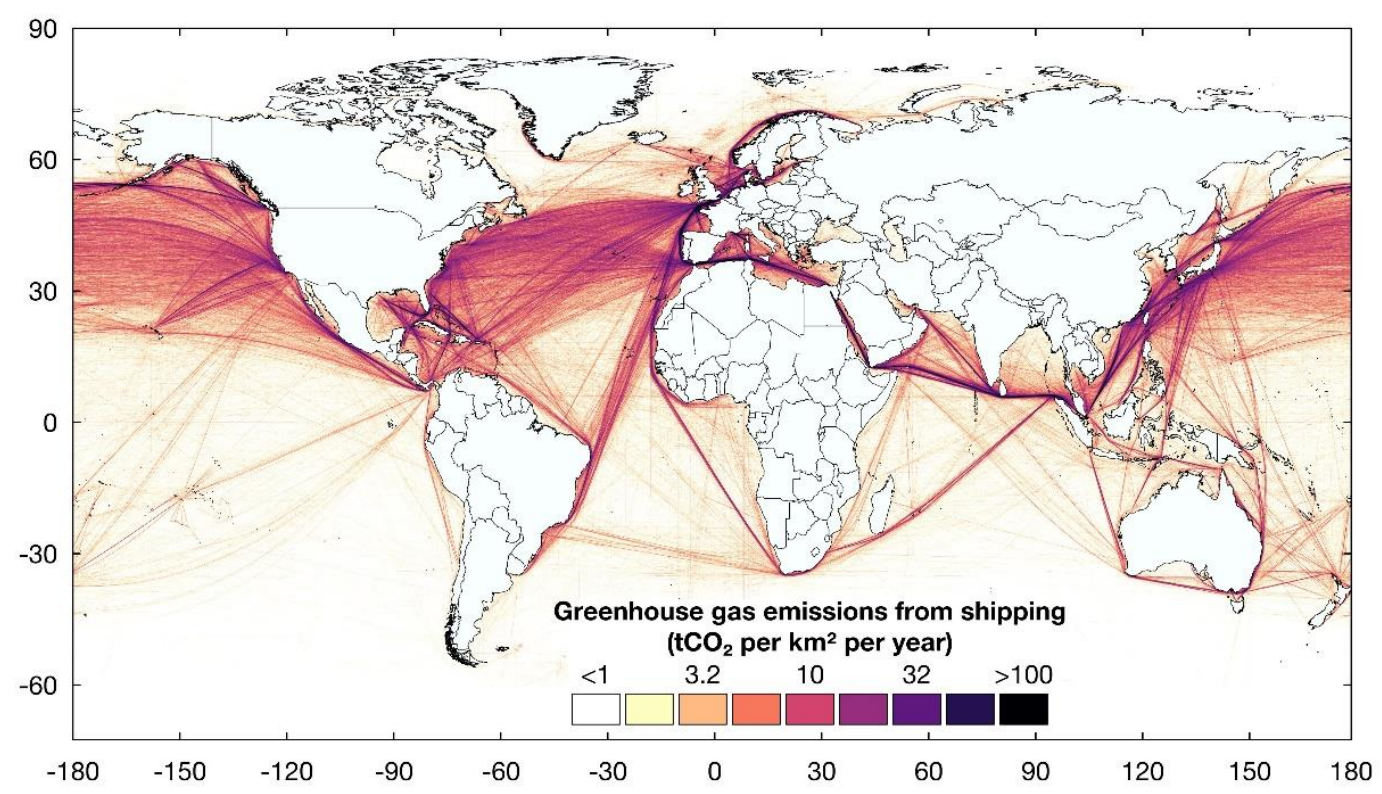

Figure 4: Map showing the global distribution of greenhouse gas emissions from shipping. Based on the intensity of shipping lane usage from [34] normalised to 2013 emissions from the sector.

The emissions from shipping is dependent on fuels and efficiencies: different fuels have varying $\mathrm{CO}_{2}, \mathrm{SO}_{x}, \mathrm{NO}_{\mathrm{x}}$ and methane emissions, and inefficient ships use more fuel. Of the approximately $300 \mathrm{Mt}$ of global maritime fuel consumption in 2015, 72\% was residual fuels (e.g. heavy fuel oil HFO), 26\% distillates (e.g. marine diesel oil) and $2 \%$ liquefied natural gas (LNG) [35]. HFO typically has a high sulphur content [36] and the contribution of international shipping to global $\mathrm{SO}_{\mathrm{x}}$ emissions in 2012 was calculated to be $13 \%$ annually [37]. $\mathrm{SO}_{x}$ emissions cause health implications, as well as causing ecosystem damage via 
acidification to water and soil [38]. In 2009, The Guardian reported that the largest 15 ships caused more sulphurous pollution than the global car fleet (760m cars) combined [39].

Sulphurous and nitrogen oxide emissions have a short-lived climate cooling effect, meaning the net impact of shipping over 20 years (based on a single year's emissions) is actually to reduce global temperatures [40]. However, the longer-term impact of GHG emissions from shipping is certainly to rise. Distillate fuels like marine gas oil (MGO) and diesel oil (MDO) have lower sulphur content, whereas GHG and $\mathrm{NO}_{\mathrm{x}}$ emissions, which arise from high temperature combustion, may be similar $[22,41,42]$.

Marine black carbon emissions also have large impacts on the climate and to human health. Black carbon is a type of fine particulate (PM2.5) that is emitted from burning HFO and to a lesser extent MDO. The GWP of black carbon varies depending on location and source, but in aerosol form has a 100 year GWP of 830 [40]. As a solid particle, atmospheric lifespan is short at 1 week [43] but global shipping emissions of black carbon account for $5-8 \%$ of annual GHG emissions on a 100 year timescale according to the ICCT [44].

\subsection{International Shipping Governance}

The IMO is a UN agency responsible for the safety and environmental regulation of global shipping; it has 172 Member States and three Associate Members [45]. IMO regulations must be ratified by over half of the member states, which are then translated into domestic law. However, the compliance process is complicated by the flag state of the respective ship and the concept of 'flags of convenience' (FOC).

FOC are those characterised by low taxation and lower regulatory measures in place and began in the 1920s when US ship owners began to register their ships in Panama after being frustrated by increased regulations and rising labour costs. As of 2015 , over $55 \%$ of global gross tonnage in the international shipping industry is registered in the top 12 FOC states, as identified by the International Transport Workers' Federation (ITF). The regional Port State Control (PSC) authorities monitor the FOCs and quantify their credibility and compliance levels.

\subsection{Shipping Emission Regulations}

The key regulation for controlling environmental impacts from shipping is the Maritime Agreement Regarding Oil Pollution (MARPOL) for $\mathrm{SO}_{\mathrm{x}}, \mathrm{NO}$ a and GHG emissions. The regulation originally focused on $\mathrm{SO}_{\mathrm{x}}$, limiting sulphur content in bunker fuel to $4.5 \%$ and gradually dropping over time as shown in Figure 5 . The global sulphur content limit is set to be reduced substantially in 2020 to $0.5 \%$, however, the global average sulphur content of HFO has not materially changed in accordance with targets [17]. 

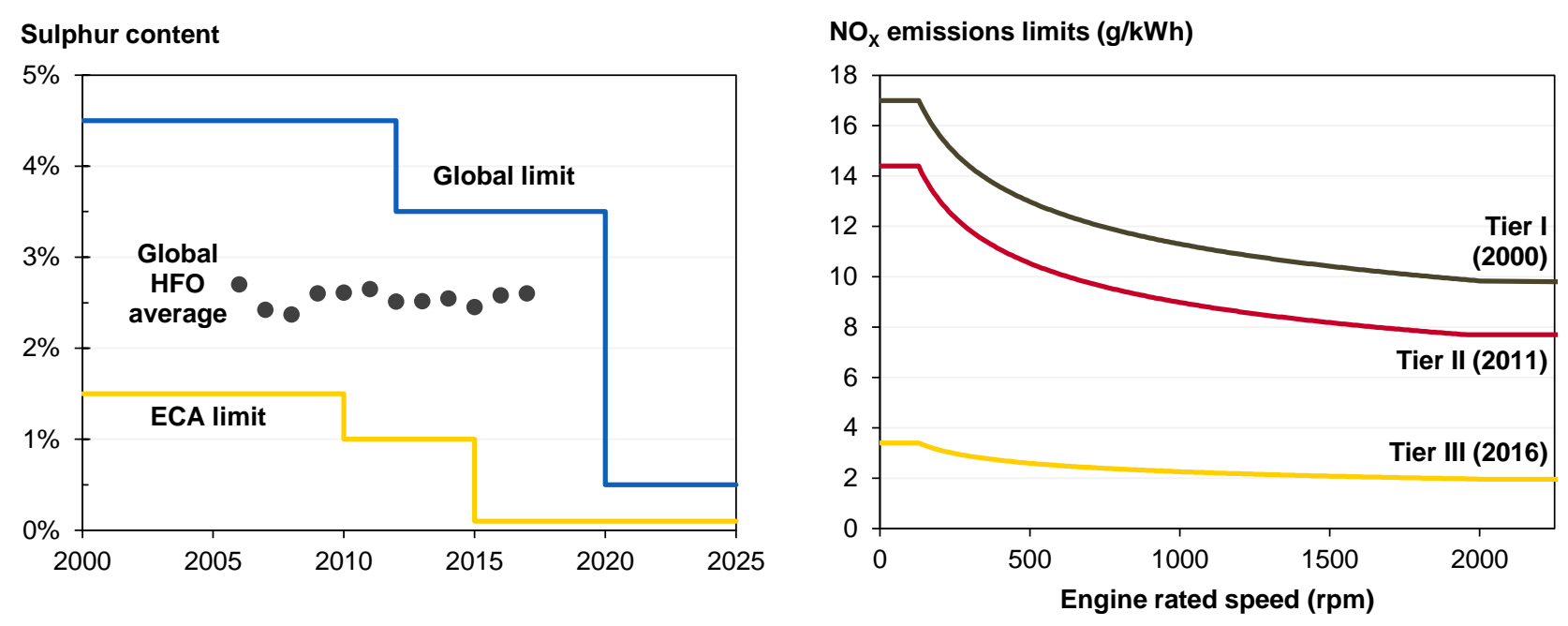

Figure 5: Sulphur and nitrogen oxides (NOx) regulations for shipping fuels. In the left panel, lines show the MARPOL Annex VI limits for open seas and in emissions control areas (ECAs); points show the global average in HFO fuel [3, 17, 32]. In the right panel, lines show the limits as a function of engine speed for open seas (Tier II) and control areas (Tier III) [48].

The IMO (through MARPOL) also set up Emission Controlled Areas (ECA), within which vessels must comply with stricter emission limits [49]. Currently there are four ECAs, in Europe and North America, which also set limits on $\mathrm{NO}_{\mathrm{x}}$ and particulate emissions [50]. MARPOL Annex VI, introduced in 1997 and strengthened in 2005 [51], incorporates regulatory limits on $\mathrm{NO}_{\mathrm{x}}$ emissions. Different tiers of compliance apply to ships with different construction dates as indicated in Figure 5, although the most stringent tier III regulations only apply to ships operating in ECAs [52].

Another addition to MARPOL in 2001 was the Energy Efficiency Design Index (EEDI), to reduce $\mathrm{CO}_{2}$ emissions for new ships via technical efficiency improvements [53]. EEDI sets a minimum energy efficiency level per capacity mile (e.g. tonne mile) for different ship types and sizes [7]. Setting the target of a $10 \%$ reduction of $\mathrm{CO}_{2}$ levels (grams of $\mathrm{CO}_{2}$ per tonne mile) by $2015,20 \%$ by 2020 and $30 \%$ by 2025 , the EEDI aims to facilitate innovation and technological improvements in shipping by tightening the target every 5 years $[53,54]$. The Ship Energy Efficiency Management Plan (SEEMP) was also introduced into MARPOL, for both new and existing ships, as a measure to improve fuel efficiency via operational improvements [51]. However, whilst there is a requirement to implement the plan, no specific fuel savings or efficiency improvements are stipulated [55].

The EEDI is currently the sole carbon emissions policy to mitigate $\mathrm{CO}_{2}$ emissions in international shipping and it is estimated that the global shipping fleet will not be fully EEDI compliant until 2040-2050 [54]. However, the reductions are negligible compared to the levels required to meet the UN 2050 global climate change targets [32]. 


\subsection{The $50 \%$ GHG emission target}

In 2018, the IMO announced an initial agreement to reduce GHG emissions by $50 \%$ by 2050 compared to 2008 emissions [10], with a solidified strategy to be produced in 2023 . This target should not be underestimated in terms of its challenge, as well as potential benefit to global decarbonisation pathways. Business-as-usual GHG emissions from the maritime industry are expected to increase significantly in the first half of this century, with IMO emission scenarios projecting growth between $50 \%$ and $250 \%$ by 2050 - depending on economic growth and development [32]. Reductions in emissions could be sourced from increasing the efficiency of vessels, such as via the EEDI, or a step change in fuel usage.

Alongside the IMO agreement, various policy measures were suggested for the short- (20182023), medium- (2023-2030) and long-term (beyond 2030). Short-term measures include strengthening the EEDI, incentivising early adoption of low carbon technologies, incentivising speed reduction/optimisation, developing carbon intensity guidelines for all marine fuels and research into innovative technologies and fuels for zero-carbon propulsion. Mid and long-term measures are to further develop the short-term measures and to consider implementing market-based-mechanisms to incentivise emissions reductions. The multitude of technical measures to meet emissions targets, and the political and infrastructural means by which to implement them, are multifaceted and are reviewed in depth for the remainder of this paper.

\section{Liquified natural gas (LNG)}

One pathway to comply with $\mathrm{SO}_{\mathrm{x}}$ and $\mathrm{NO}_{\mathrm{x}}$ requirements and to reduce $\mathrm{CO}_{2}$ emissions is via LNG as a fuel. Natural gas is liquefied by cooling to $-162^{\circ} \mathrm{C}$ and thus takes up 600 times less space for storage and transportation [58]. There are four main types of LNG engine/turbine in use today: lean-burn spark ignition; low pressure dual fuel (4- and 2-stroke); high pressure dual fuel; and gas turbine [59]. Each have different operational characteristics, efficiencies and exhibit significantly different emission profiles [59]. LNG has been used for the propulsion of LNG carrier vessels for more than 40 years, by using the boil-off gas created in the storage tanks to run dual-fuel engines [60].

The first dedicated LNG-fuelled vessel was built in 2000. In 2017, there were 117 LNGfuelled vessels (non-LNG carriers) in commercial operation, with many new LNG-fuelled vessels currently under production $[59,61]$. Current vessels are mainly operate in Europe due to the expansive ECAs, and most new vessels are planned in Europe (57\%) and North America (38\%) due to emissions regulations and underlying fuel prices [62], [53]. 


\subsection{Environmental impacts}

The potential benefits of LNG over conventional liquid fuels relate chiefly to $\mathrm{NO}_{\mathrm{x}}, \mathrm{SO}_{\mathrm{x}}$, particulates and $\mathrm{CO}_{2}$ emissions. Natural gas has a higher hydrogen-carbon ratio than liquid fossil fuels [63], resulting in 20-30\% lower $\mathrm{CO}_{2}$ emissions on combustion [64]. However, the relative improvement in $\mathrm{CO}_{2}$ emissions may be negated by methane emissions, in particular through engine slip $[22,59]$. Slip occurs where some methane fails to combust in the engine, resulting in leakage to the atmosphere [60]. Additionally, leakage may occur in other parts of the drive train, as well as across the natural gas supply chain in general $[53,65,66]$. Methane is a potent, albeit short-lived, greenhouse gas and has a global warming potential (GWP) 36 times stronger than $\mathrm{CO}_{2}$ on a 100-year time horizon [40]. Currently, LNG engines have a methane slip of $2-5 \%$ of total throughput, although estimates from high-pressure dual fuel 2-stroke are substantially lower $[61,67]$.

There are various estimates of life cycle GHG emissions from using LNG as a shipping fuel $[18,22,67-69]$, a summary of which is given in Figure 6 including the impact of upstream supply chain and ship bunkering and operation. Upstream impacts arise from resource extraction, processing and liquefaction and transportation, while downstream emissions are from combustion and leakage (slip). Studies typically estimate a relative decrease in emissions by switching from distillate (e.g. MDO) or residual fuel (HFO) to LNG of approximately $8-20 \%$. Upstream emissions chiefly arise from the energy-intensive liquefaction process, which may use $8-12 \%$ of the natural gas throughput as fuel duty [70], as well as methane emissions from the supply chain. Emissions from the ship are governed by the engine efficiency and the engine methane slip [71]. Therefore, reductions in methane emissions are imperative if LNG is to contribute to the $50 \%$ GHG reduction target. If the total methane emissions were 5.5\% over its life cycle, then the global warming potential of LNG would the equal that of HFO, MDO or MGO [61].

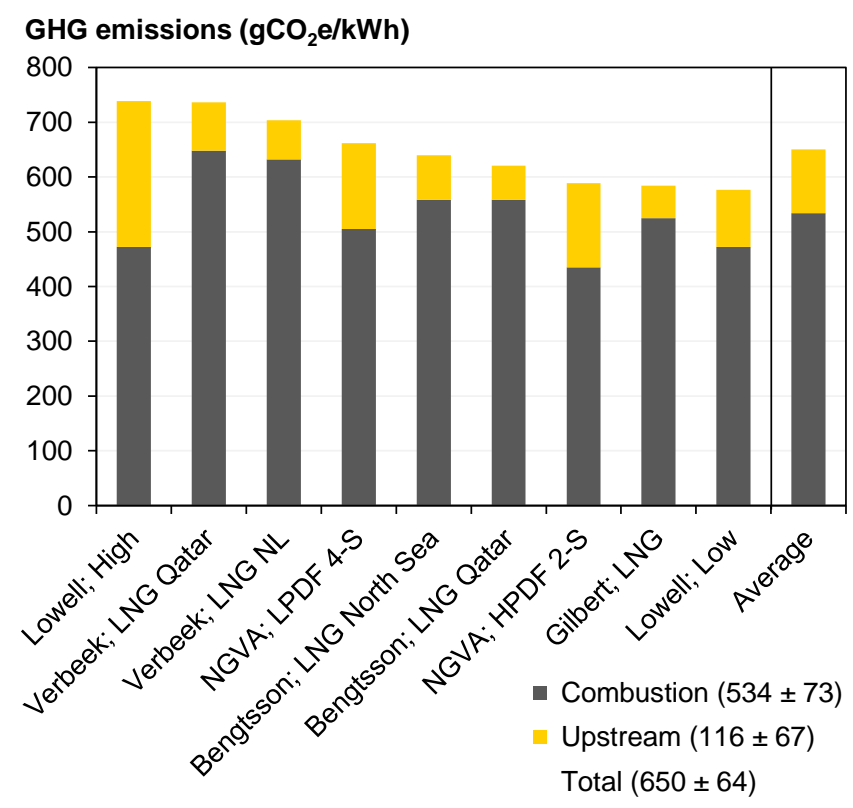


Figure 6: Various estimates of GHG emissions from LNG-fuelled ship engines expressed per kWh of engine output, split into upstream supply chain and ship emissions. Data from: $[18,22,67-69]$.

LNG does not contain sulphur, meaning that the $\mathrm{SO}_{\mathrm{x}}$ emissions are theoretically reduced to zero. In dual-fuel engines a small fraction of oil-based fuel is needed for ignition [63] but reductions in $\mathrm{SO}_{\mathrm{x}}$ emissions may still reach $90-99 \%$ compared to HFO $[59,72]$. Particulate matter (PM) is also almost completely eliminated [60].

$\mathrm{NO}_{x}$ emissions are significantly lower in a low-pressure dual-fuel engine system than liquid fuels. $\mathrm{NO}_{\mathrm{x}}$ emissions are dependent on the combustion temperature, with higher temperatures resulting in more $\mathrm{NO}_{\mathrm{x}}$. A lean fuel-to-air ratio achievable with some LNG engines and the higher proportion of gas with a dual fuel engine enables a lower combustion temperature [73] and reduced $\mathrm{NO}_{\mathrm{x}}$ emissions of $75-90 \%$ relative to $\mathrm{HFO}[59,63$, 72]. However, there is a trade-off between $\mathrm{NO}_{x}$ and methane emissions: low temperatures favour low $\mathrm{NO}_{\mathrm{x}}$ emissions, while higher temperatures result in less methane slip. For high pressure dual fuel engines, methane slip may be reduced to $~ 0.2 \%$ of throughput [67], but $\mathrm{NO}_{\mathrm{x}}$ emissions would not meet tier 3 standards without further exhaust treatment [59].

For dual-fuel engines, the relationship between fuel blend and $\mathrm{CO}_{2}$ emissions is broadly linear, but significant $\mathrm{NO}_{\mathrm{x}}$ emission reductions are only seen below a $30 \%$ share of diesel [73]. Therefore without additional exhaust gas treatment technologies, for example selective catalytic reduction (SCR), the proportion of oil fuel will be limited by the $\mathrm{NO}_{\mathrm{x}}$ emissions regulations set out in the $\mathrm{NO}_{x}$ ECAs.

\subsection{Fuel Costs for LNG}

The North American shale gas boom and resultant fall in gas price has increased the viability of LNG as a marine fuel outside Europe [74]. Figure 7 shows the average fuel prices for different available shipping fuels, assuming current average engine efficiencies: $L N G=6.2$ $\mathrm{kWh} / \mathrm{kg}$ fuel $[59,67] ; \mathrm{HFO}=5.0 \mathrm{kWh} / \mathrm{kg}[22,69] ; \mathrm{MDO}=5.4 \mathrm{kWh} / \mathrm{kg}[22,67,69] ;$ methanol $=2.5 \mathrm{kWh} / \mathrm{kg}$. After 2008, the freight market went into recession whilst bunker prices spiked, leading a search for alternative fuel sources [53]. In 2015 the HFO price dropped again, but even with increased competitiveness in the prices, there is still interest in LNG as a marine fuel due to the environmental drivers. 


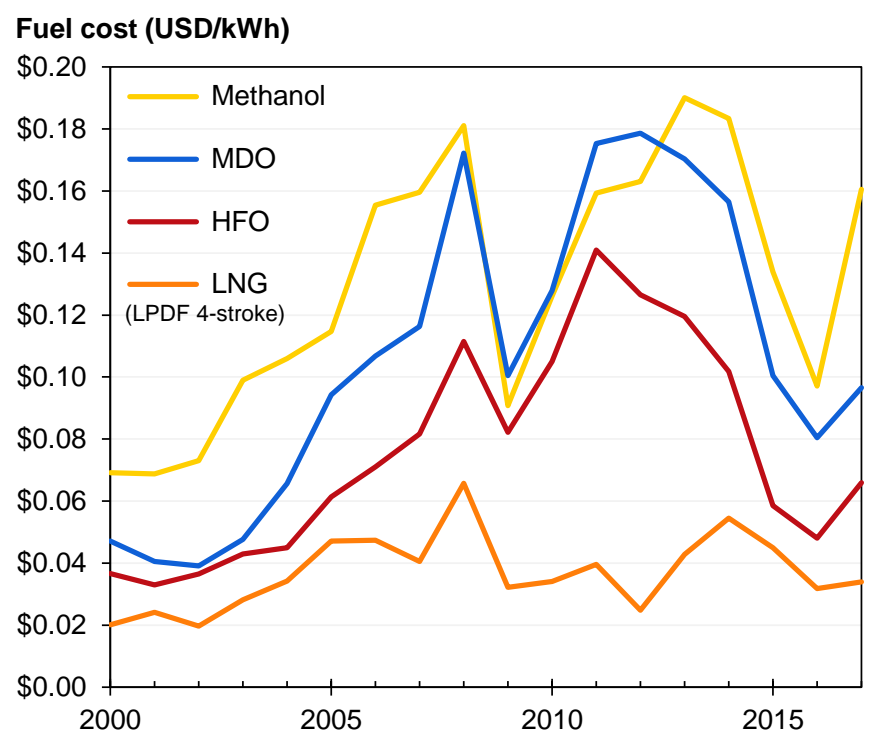

Figure 7: Average fuel costs for each year for different fuels per kWh of engine output.

LPDF 4-stroke $=$ low pressure dual fuel 4 stroke run on LNG. Average fuel costs per tonne from [14, 75-81] are converted to engine output using standard engine efficiencies.

The price of LNG is generally lower than HFO, whereas MDO is approximately $50 \%$ more expensive than HFO. However, the price of LNG as a marine fuel includes much uncertainty, through variable gas prices and the cost of new LNG infrastructure required for international trade routes $[53,74]$. These added costs are estimated to be between 50 USD/t and $630 \mathrm{USD} / \mathrm{t}$ on top of the indexed gas prices [74].

\subsection{Capital Costs for LNG}

Table 1 shows the capital costs (CAPEX) for the engine and exhaust technologies associated with various fuels. The cost associated with MGO engine conversion is relatively small [74], whereas Wang and Notteboom [64] estimate the capital cost for an LNG-fuel vessel relative to an oil-fuel equivalent is $20-25 \%$ more expensive. However, the cost of the LNG propulsion technologies may lower as technology production rates increase [82].

Table 1: Cost of installing fuel technologies to current ships and new builds. Data from [74]. $\mathrm{MGO}=$ marine gas oil; $\mathrm{SCR}=$ selective catalytic reduction; $\mathrm{EGR}=$ exhaust gas recirculation; Values in 2012 US Dollars.

\begin{tabular}{lll}
\hline Compliance Strategy & Retrofit cost & Newbuild cost \\
\hline MGO - engine conversion, SGR, EGR & $\$ 180,000+\$ 75 / \mathrm{kW}$ & $\$ 140,000+\$ 63 / \mathrm{kW}$ \\
HFO and scrubber - scrubber and SCR & $\$ 600 / \mathrm{kW}$ & $\$ 2,200 / \mathrm{kW}$ \\
LNG four stroke duel fuel - LNG tanks, etc. & $\$ 800 / \mathrm{kW}$ & $\$ 1,600 / \mathrm{kW}$
\end{tabular}




\begin{tabular}{lll}
\hline LNG two stroke dual fuel - LNG tanks, etc. & $\$ 700 / \mathrm{kW}$ & $\$ 1,500 / \mathrm{kW}$ \\
LNG four stroke spark ignition - LNG tanks, etc. & $\$ 800 / \mathrm{kW}$ & $\$ 1,600 / \mathrm{kW}$ \\
\hline
\end{tabular}

LNG storage tanks require approximately twice the volume of the conventional bunker tanks for the same energy content, due to the density difference. This can cause issues when retrofitting and a hull modification may be needed [60], thus it is technologically and economically favourable to design LNG systems for new-build projects [74].

The cost of adding port infrastructure may also be significant [83]. LNG propulsion have the largest economic advantage for those vessels operating for the highest proportion of their sailing time in the ECAs. Most vessel voyages are categorised either as those that spend greater than $80 \%$ of their sailing time in the ECA zones and those that spend less than $5 \%$ of their time in ECA zones [60]. For those that spend less than $5 \%$ of their time in ECA zones, there is little incentive to switch to LNG propulsion as they may continue to use HFO and switch to MDO for the short periods of time in ECAs and ports [53]. Consequently, the current emissions standards are not satisfactory to create economic incentives large enough to cause a fuel change to LNG in the larger vessels with more global voyages.

\section{Alternative Fuels}

Whilst LNG offers advantages over liquid fossil fuels via reduced air quality emissions, it may not be enough to meet more stringent climate targets. Nuclear, renewables and biofuels also have potential to reduce shipping $\mathrm{CO}_{2}$ emissions and range from economically feasible short-term options to less developed long-term options. Figure 8 shows the range of literature estimates of life cycle GHG emissions for different ship fuels. Broadly, biofuel options (bio-LNG, biomethanol and other bio-liquids) exhibit the lowest emissions, whilst conventional methanol fuel exhibits the highest emissions. Each alternative fuel is discussed in the following section, with respect to their environmental and economic credentials, as well as resource/political availability. 


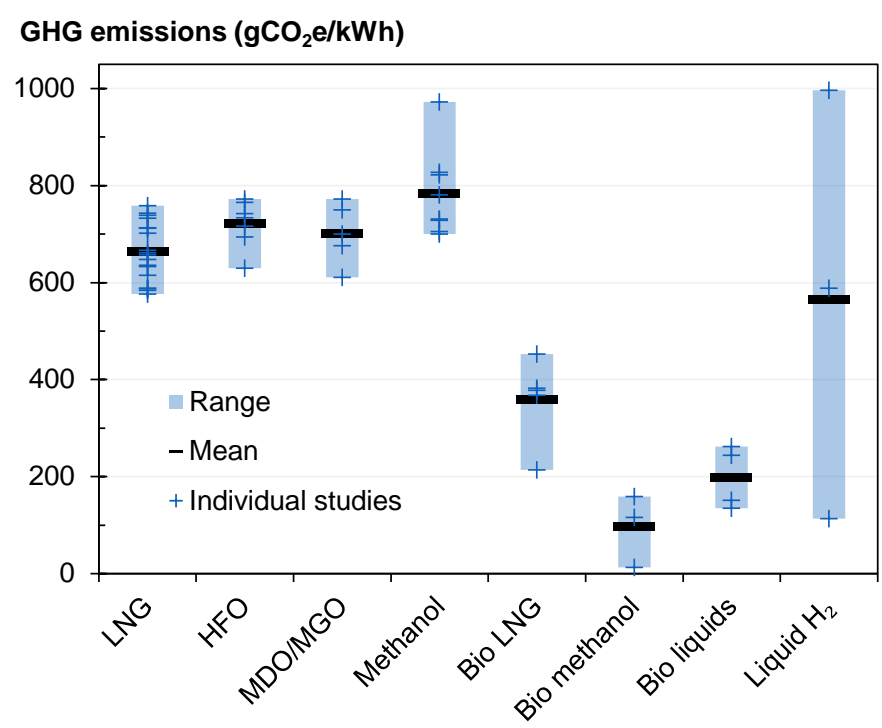

Figure 8. Literature estimates of total life cycle GHG emissions for different categories of fuels. Blue circles represent individual literature estimates, red bars represent mean value for each category. Data from [18, 22, 42, 67-69, 84-87].

\subsection{Biofuels}

Biofuels may offer large GHG emission reductions and in some cases can be used as a 'dropin' fuel, requiring very little alteration to the incumbent engines [88]. First generation conventional biofuels are readily available today in significant quantities, including straight vegetable oil (SVO), hydrotreated vegetable oil (HVO), fatty acid methyl ester (FAME) and bio-ethanol. However, the use of conventional biofuels is restricted internationally due to sustainability issues associated with large scale production. The use of waste oils can mitigate these concerns but the availability of waste oils for large scale production are a barrier.

Advanced biofuels use feedstocks with fewer sustainability concerns. The most applicable advanced biofuels to international shipping applications are Fischer-Tropsch diesel (FTDiesel), pyrolysis oil, ligno-cellulosic ethanol (LC Ethanol), bio-methanol, dimethyl-ether (made of bio-methanol) and bio-LNG. In general, advanced biofuels have lower GHG emissions than conventional biofuels, as shown in Figure 9. The figure shows a broad range of emissions estimates both across and within the biofuel categories. Note that the lowest values for FAME and HVO are using waste oils. 


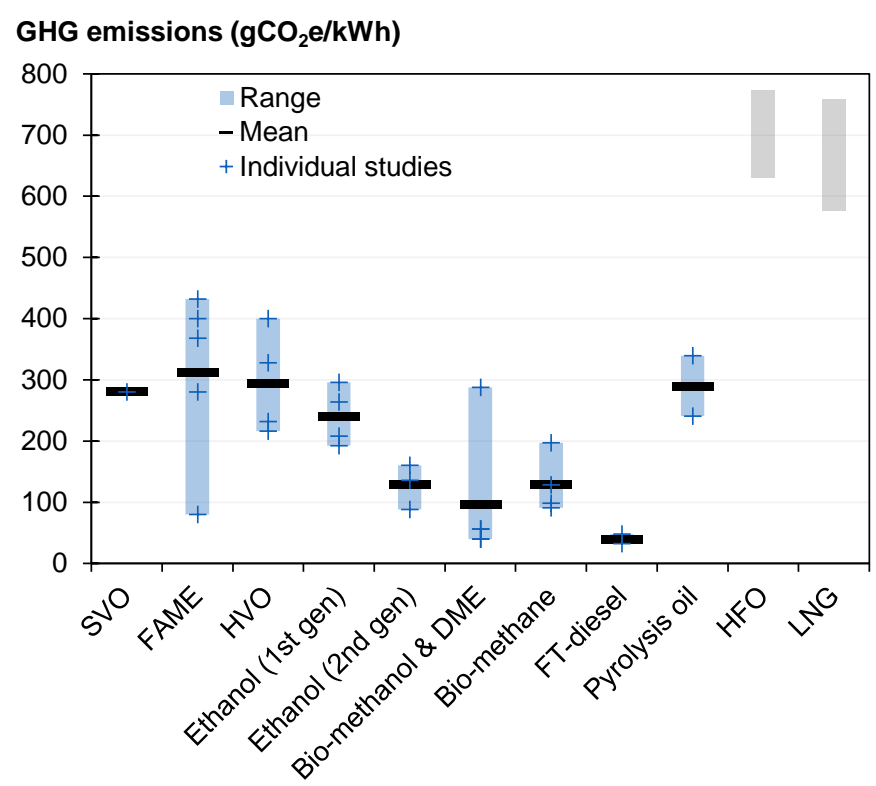

Figure 9: Overview of GHG emissions for comparison of selected biofuels and fossil fuels. Data from $[86,89]$.

Biofuels could help to achieve $\mathrm{NO}_{\mathrm{x}}, \mathrm{SO}_{\mathrm{x}}$ and GHG emissions reduction targets. All biofuels contain very little sulphur [86]. FAME for example has very low sulphur content ( $20 \mathrm{ppm}$ ) and exhibits lower NOx and PM emissions than marine gas oil [87]. Additionally, biofuels are biodegradable which is an advantage over fossil fuels with respect to accidental spills [86].

Diesel-like fuels, such as SVO, HVO, FAME, FT-diesel and pyrolysis oil can be used in current marine diesel engines with no or small engine modifications and can also use the current storage and bunkering infrastructures [86]. Alcohols and gaseous fuels like bio-ethanol, biomethanol, bio-LNG and bio-DME require more significant changes to engine, storage and bunkering infrastructure, incurring additional capital costs. They all require spark ignition engines, dual fuel compression ignition engines or converted compression ignition engines, given their lower cetane number (with the exception of DME) and cannot self-ignite [90].

A barrier to biofuels uptake is the price differential between incumbent fuels like HFO, MDO and the biofuels. For example, the IEA estimate a 2016 FAME price of 1,040 USD/t and HVO of 542 USD/t, effectively double the fuel price of their fossil counterparts MDO (482 USD/t) and HFO (290 USD/t), respectively [88]. Costs are higher for advanced biofuels with the larger GHG emission savings and fewer sustainability concerns, due to the complexity and immaturity of the production processes.

There is also disagreement on whether current GHG emission accounting practices are fit for purpose [91]. The magnitude of biogenic carbon emissions factors vary considerably over time [92], signalling the need for strong oversight of supply chains and forest management [93]. Given differing agricultural and processing requirements, and the 
variability across different biofuel sources, ensuring low environmental impacts across the biofuel supply chain is a major challenge. Strong legislative frameworks and incentives for bioenergy, for example via the EU's Renewable Energy Directive, is one way to mandate sustainable practices [86]. However, some national and regional policies are not yet in favour of biofuels and the current classification does not differentiate between biogenic carbon and fossil carbon content in the Energy Efficiency Design Index (EEDI) [86].

The wider implications of biofuels involve complex trade-offs in utilising resources that involve human essentials such as food and water [94]. The global potential for biofuels will be heavily constrained once vital crops and land needed to supply food for a growing world population are accounted for, which includes constraints on water and fertilizers to grow second-generation fuel crops [95]. Some studies have even omitted biofuels from global sustainable energy scenarios due to the potential for air pollution during cultivation and reprocessing, and because carbon neutrality may be unobtainable due to the sacrifice of forests for arable land. Nevertheless, in practice, second-generation biofuels are likely to play some role for transport in conjunction with renewable electricity [96], but will not be capable of meeting the total demand [95].

In summary, biofuels offer compatible replacements to the incumbent fossil marine fuels in the short- and medium term. The GHG reduction potential is higher for second generation biofuels, where FT-diesel and pyrolysis oil are compatible with diesel infrastructure. Other second-generation fuels such as LC ethanol, bio-methanol, DME and bio-LNG would require much larger changes to engines, storage and infrastructure. The cost and availability of the biofuels, particularly advanced biofuels, is a barrier and they will not compete with fossil fuel alternatives, unless a strong GHG reduction policy, or carbon price, is introduced. Even then, resource must be managed to ensure impacts on broader agriculture and food resources are minimised.

\subsection{Methanol}

Methanol fuel for ships has received some attention and there is currently one marine engine available that may run on methanol as a dual fuel. To date (2018) there are 7 methanol-fuelled ships in operation, with another 4 planned to be in operation by 2019 [97]. Methanol combustion in marine engines produces modest $\mathrm{CO}_{2}$ reductions and low emissions of other pollutants, relative to HFO or MGO [22, 42]. Stena Germanica, the world's first methanol-powered sea vessel, is suggested to have reduced $\mathrm{SO}_{\mathrm{x}}$ emissions by $99 \%, \mathrm{NO}_{x}$ by $60 \%$, particulates by $95 \%$ and $\mathrm{CO}_{2}$ by $25 \%$, thus complying with the latest $\mathrm{ECA}$ regulations on its Baltic Sea route [98].

Methanol can be produced from many sources, including natural gas, from catalytic hydrogenation of a waste $\mathrm{CO}_{2}$ stream or from biomass. In the case of a biomass feedstock, $\mathrm{CO}_{2}$ emissions are biogenic and may be discounted (see section 4.1 for discussion). 
However, the methanol supply chain produces significant emissions depending on its feedstock and process. The use of methanol from natural gas results in significantly lower air quality emissions, but life cycle GHG emissions are around $10 \%$ higher than from HFO or MDO (see Figure 8), due to the natural gas supply chain, gas reforming and methanol synthesis. If waste $\mathrm{CO}_{2}$ is to be used (with renewable hydrogen) to produce methanol, great care must be taken in carbon accounting: it is not necessarily appropriate to suggest that, if it is a thermogenic waste product, emissions are discounted. Thus, life cycle emissions associated with methanol from catalytic hydrogenation may be significant, but no studies that estimate emissions from this production route were found.

The cost of methanol as a fuel is greater than liquid fossil fuels and LNG, as shown in Figure 7. Thus, whilst air quality emissions may be significantly reduced, the carbon credentials of methanol fuel must be proven and then incentivised to encourage further uptake.

\subsection{Hydrogen with marine fuel cells}

Fuel cells are an efficient way of producing low carbon electricity [99], but the availability of hydrogen and its low volumetric energy density require significant additional infrastructure and system design [95]. Hydrogen fuel cells exhibit no direct greenhouse gas emissions, but emissions associated with the hydrogen supply chain must be considered. Feedstock impacts are highly variable, be it renewable electrolysis, natural gas reforming or biomass gasification $[100,101]$. This is demonstrated in Figure 8 , where three estimates of total GHG emissions from $\mathrm{H}_{2}$ fuel cells exhibit high variability (from 113 to $997 \mathrm{gCO}_{2} \mathrm{eq} . / \mathrm{kWh}$ ), with the low emissions using renewable electrolysis, the central emissions using natural gas with carbon capture and storage (CCS), and the highest value using natural gas reforming without CCS [22].

An advantage of fuel cells is that they generate little noise or vibrations, whilst marine ecosystems are currently affected by the highly acoustic nature of shipping [102]. The silent electric motors for propulsion have a high efficiency ( 95\%) and when combined with 45\% efficient fuel cells show a significant improvement over internal combustion engines [102]. A diesel generator and micro gas turbine requires $44 \%$ more fuel than a fuel cell of the same output power [103].

There are relatively few hydrogen fuel cell ships in operation today, with DNV GL recording 23 fuel cell shipping projects at different stages of development in 2017 [104]. The first civilian ship to utilise fuel cell technology for supplementary propulsion was the Viking Lady. Main propulsion was provided by LNG in a diesel engine, with a fuel cell that operated on hydrogen or methanol (with reconfiguration). This system reduced $\mathrm{SO}_{\mathrm{x}}$ by $100 \%, \mathrm{NO}$ by $85 \%$ and $\mathrm{CO}_{2}$ by $20 \%$ [105]. The 'ZemShip' (Zero Emission Ship) FCS Alsterwasser, a hydrogen 
fuel cell ship based in Hamburg's port, has 100 passenger capacity and a power rating of $100 \mathrm{~kW}$ for operation on rivers and small waterways [106].

Storage of hydrogen is typically as a compressed gas (up to 700 bar), as a liquid (cryogenic) or in solid state (metal hydrides) [102]. Large storage volumes may be a barrier to implementation, particularly for retrofits. Table 2 shows the cargo volume and mass impacts for hydrogen versus HFO and LNG: liquid hydrogen requires 8 times more storage volume than HFO and 30 times more for compressed hydrogen. Hydrogen could also be stored as liquid ammonia, which does not require such low temperatures $\left(-33^{\circ} \mathrm{C} \mathrm{cf}\right.$. $-254^{\circ} \mathrm{C}$ for liquid hydrogen), giving reduced parasitic energy requirements [107]. Ammonia could be used directly for propulsion, either via a combustion engine or in a fuel cell [108]. No technologies have yet been commercialised for marine operation, although some dual fuel engines are under development $[109,110]$.

Table 2: Cargo volume and mass impacts for different fuels, for a vessel with a 5.1 day range. Data from $[111,112]$.

\begin{tabular}{lrrcc}
\hline \multicolumn{1}{c}{ Fuel } & HFO & LNG & $\begin{array}{c}\text { Compressed } \\
\text { hydrogen }\end{array}$ & $\begin{array}{c}\text { Liquid } \\
\text { hydrogen }\end{array}$ \\
\hline Density $\left(\mathrm{kg} / \mathrm{m}^{3}\right)$ & 1010 & 470 & 23.7 & 72.4 \\
Daily fuel use $\left(\mathrm{m}^{3}\right)$ & 83 & 203 & 1186 & 522 \\
Fuel mass for voyage $(\mathrm{t})$ & 421 & 485 & 140 & 140 \\
Tank volume $\left(\mathrm{m}^{3}\right)$ & 417 & 1195 & 12140 & 3120 \\
Mass of tanks $(\mathrm{t})$ & - & 450 & 8584 & 972 \\
& - & & & \\
Containers displaced & - & 96 & 372 & 180 \\
Volume displaced $\left(\mathrm{m}^{3}\right)$ & - & 3700 & 14340 & 6939 \\
Weight displaced $(\mathrm{t})$ & - & 1258 & 4878 & 3123 \\
\hline
\end{tabular}

Cargo shipping must comply with the International Code for the Construction and Equipment of Ships Carrying Liquefied Gases in Bulk (IGC Code), but the IGC code does not currently allow for the transportation of liquid hydrogen. Changes to the code are being developed and cargoes not covered by the code can be carried if there is an agreement between relevant nations [113]. For example, Australia and Japan recently signed a memorandum at the Australian Maritime Safety Authority (AMSA) which permits liquid hydrogen to be shipped in bulk for the first time [113].

Prohibitive capital costs for new infrastructure are a barrier to global commercialisation. Some natural gas infrastructure could be used for hydrogen, which could drastically reduce capital costs, particularly in countries with a gas-grid network [114]. Hydrogen fuel costs are higher, potentially by an order of magnitude, than conventional fuels [111], but this gap 
should decline as electrolysers fall in cost [115]. Estimates of retail costs for hydrogen vary from around 0.06 to $0.24 \mathrm{USD} / \mathrm{kWh}$ fuel energy content with an average of $0.12 \mathrm{USD} / \mathrm{kWh}$ [116], reflecting a wide range of potential feedstocks and conversion processes. In comparison, the 2017 estimate for MDO was 0.04 USD/kWh energy content (not including energy efficiency losses as depicted in Figure 7). Thus, strong incentives are needed to encourage uptake of hydrogen.

The cost of introducing hydrogen could be reduced by selecting a small number of large vessels that are limited to point-to-point routes between highly developed ports with the available infrastructure (e.g. Rotterdam and Tokyo) or within a small geographic area (e.g. North Sea) [117]. However, despite the potential of some fuel cell technologies, the highpower demand required to propel large ships is not yet viable with current fuel cell technology and so will not replace the existing multi megawatt main engines of large ships in the foreseeable future [118].

\subsection{Electric propulsion systems}

As with the propulsion in hydrogen fuel cell ships, electric propulsion (EP) systems feature an electric motor supplied by a device that contains a stored form of electrical energy [96]. The environmental impact is determined by the source of the stored energy, for example stored hydrogen or electrical energy can be produced from fossil fuels. Regardless, developing the required infrastructure could increase the industry's flexibility, creating a potentially low carbon pathway. The company 'Norwegian Electric Systems' (NES) is currently developing and integrating hybrid engines and EP systems [119]. Two of its ferries shall be operating on routes with strict emission requirements as designated by the Norwegian Road Authorities, which has resulted in the development and deployment of an EP system using chargeable lithium ion batteries [119]. No economic assessments of electric propulsion ships were found to date, but cost-effectiveness will be governed primarily by battery costs, which are falling rapidly [120], and the cost of electricity or fuel used for charging.

\subsection{Nuclear Marine Propulsion}

Nuclear fuel offers high power density with low and stable fuel prices, very low greenhouse gas and air quality emissions, and the ability to operate for long periods without refuelling. Nuclear propulsion is achieved via a small onboard nuclear plant heating water to raise steam, which drives steam turbines and turbo generators. While used extensively for military warships and submarines, the development of a civilian nuclear fleet faces many hurdles with public and political perception, legislation and training, and safety against catastrophic accidents, terrorism and non-proliferation. 
In 2016, it was estimated that 166 naval reactors are in operation: 85 owned by the US, 48 by Russia and 33 across the rest of the world [121]. To date there have only been four commercial nuclear vessels; the Russian Sevmorput is currently the only one active [122]. However, this ship experiences restrictions in which ports it can visit, due to civilian evacuation plans and fears at docks [123]. Uptake in the commercial sector could utilise small modular reactor (SMR) technology, sized at a few hundred MW [124], but remain an early-stage concept [125]. An example is the 'RITM-200' reactor for icebreakers such as the NS Arktika, with a seven-year refuelling cycle. The cost, with two $175 \mathrm{MW}$ steam generators is approximately $\$ 1.9$ billion per vessel $[124,126]$.

However, control of nuclear material is a significant security and geopolitical concern. Highly-enriched uranium (30-90\% $U_{235}$ ) is used in Russian naval reactors and could be subverted into an improvised weapon [121]. Proposals to limit the use of highly-enriched uranium in the civilian sector are progressing with support of the International Atomic Energy Agency [124], and other nations' civilian nuclear vessels have used low-enriched uranium.

Safety concerns may be an insurmountable barrier to wider adoption. There are seven nuclear power reactors at the bottom of the ocean due to naval incidents, and the US Navy has released radioactive water during fuelling operations [127]. Further challenges involve the distribution, testing and monitoring of technologies and components needed for reactors, fuel production and decommissioning [125]. Retired nuclear vessels are ultimately still stored afloat, indicating that a permanent solution has not been established [125]. Due to public perception, the lack of precedent and shortfalls in legislative frameworks, trained personnel and infrastructure, the potential for large scale deployment before 2050 is low.

\section{Vessel Efficiency Improvements}

Several operational and technological changes could reduce shipping emissions (and fuel use) via increased efficiency, such as the use of wind propulsion assistance, slow steaming, low resistance hull coatings and waste heat recovery systems. Each are described below with respect to their decarbonisation potential, costs and applicability.

\subsection{Wind assistance}

Wind power is being widely developed through both conventional sails and modern alternatives. These include Flettner rotors, kites or spinnakers, soft sails, wing sails and wind turbines [128]. They cannot provide a typical ship's total propulsion power by themselves, but as wind speeds are generally highest in the high seas [129], they allow large fuel savings whilst maintaining full speed $[108,130]$. Wind propulsion is most effective at slower speeds (e.g. less than 16 knots) [131] and on smaller ships (3,000-10,000 tonnes) [132], which 
account for one-fifth of global cargo ships. The compatibility of different designs varies between ship classes due to potential interference with cargo handling [128, 133].

Various studies have estimated fuel savings across a wide range: 2-24\% for a single Flettner rotor, $1-32 \%$ for a towing kite [133], up to $25 \%$ for the eConowind sails (which pack into a single container) [134] and some estimate savings from $10-60 \%$ at slow speeds [131]. Several shipping companies have trialled adding sails to cargo vessels [135], but gradual uptake is not predicted until 2025 due to their relative immaturity [128]. Additionally, unfamiliarity with technology, safety and reliability concerns, as well as a lack of demonstration have been primary barriers to broad adoption across a relatively risk-averse industry [136]. No data on capital costs were found for the installation of wind assistance systems as they are at an early stage of development, but the potential fuel savings are large and further research is required to determine cost-effectiveness under different operational conditions and ship types.

\subsection{Solar assistance}

Several carriers are also testing solar assistance, including hybrid sail systems which utilize both wind and sunlight to preserve limited deck area. Examples include automated kite sails from SkySails, a 3,000 tonne 'zero-emission' cargo carrier vessel from B9 Shipping, and the UT Wind Challenger hybrid freighter with nine solar sails [135], the EMP Aquarius [137] and Nichioh Maru [108].

The attainable energy would only be sufficient to augment the auxiliary power demands $[128,138]$, while the erosion of solar panels by the salty marine environment also poses a barrier. The potential $\mathrm{CO}_{2}$ reduction reported in different studies for solar energy generation on-board vessels range from $0.2-12 \%$ [20], while wind-solar hybrid systems may increase fuel savings to $10-40 \%$ [135]. As with wind assistance, no capital or operating cost data were found and further research is required to determine potential cost-effectiveness.

\subsection{Slow steaming}

Full speed for a container ship is normally between $23-25$ knots $(44 \mathrm{~km} / \mathrm{h})$; slow steaming is defined as 20-22 knots (39 km/h), extra slow as $17-19$ knots ( $33 \mathrm{~km} / \mathrm{h}$ ) and super slow as 15 knots $(28 \mathrm{~km} / \mathrm{h})$ [139]. Slow steaming lengthens round-trip time by $10-20 \%$ depending on the service route and port times [140], but reduces fuel consumption and $\mathrm{CO}_{2}$ emissions by raising vessel efficiency, as shown in Figure 10 [139-142]. Longer transport times associated with slower speeds means more ships or load is required, which reduces the saving. However, a $10 \%$ reduction in speed may result in a total average emissions reduction of $19 \%$ [21]. The benefits of slow steaming are varied across different ship types, sizes, routes and duties [143]. Additionally, slow steaming alters engine operating conditions, which could increase fouling and corrosion due to low operating temperatures and poor combustion 
$[141,142]$. Fouling of the hull also impacts the drag of the vessel that again will increase fuel consumption.

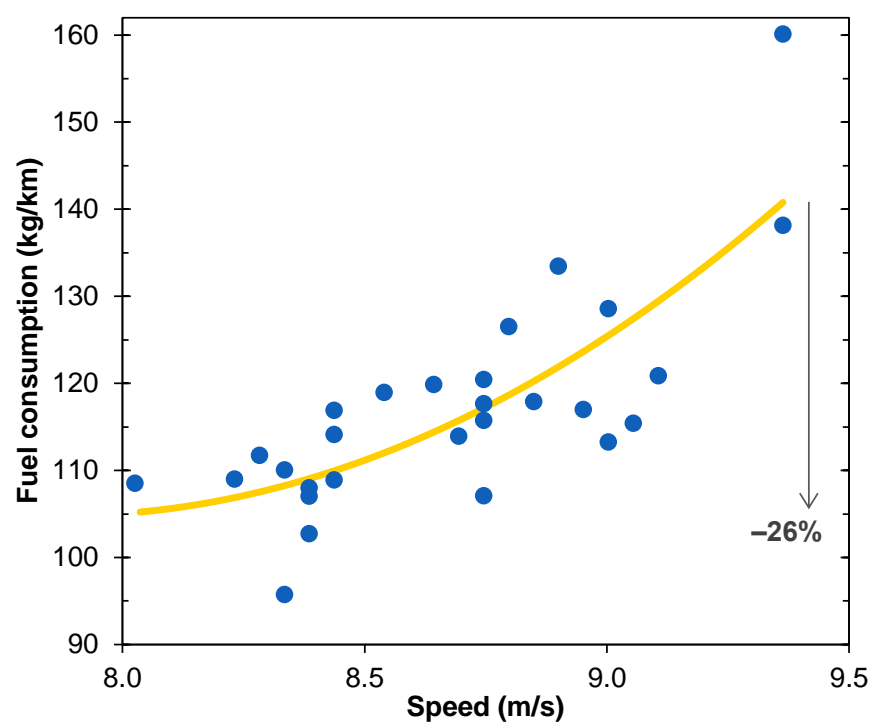

Figure 10: Fuel consumption of sea vessels versus average speed. Data from [140].

Cariou [144] estimates that slow steaming reduced emissions by $11 \%$ from container ships between 2008 and 2010 . The greatest reduction was for vessels on large trade routes (multi-trade and Europe/Far East), in contrast to smaller trades such as Australia/Oceania related trades which are subject to less slow steaming [144]. The IMO suggests that container ships, oil tankers and bulk carriers reduced their specific fuel consumption by $30 \%$ between 2007 and 2012 through slow steaming [32].

As shippers and freight forwarders move to 'just-in-time' delivery, slow steaming may improve the reliability of scheduling, as vessels can speed up to make up time if needed. Slow steaming could also absorb excess fleet capacity during periods of slack demand: in 2010 for example, $40 \%$ of potentially excess capacity was absorbed by slow steaming [141].

Fuel costs provide a significant incentive to slow steam, accounting for up to $50 \%$ of total operating costs, and is anticipated to rise with the introduction of climate related policies [145]. However, while slow-steaming for fossil-fuelled ships can reduce costs, the benefits are not necessarily felt by cargo owners unless those lower fuel costs translate into lower freight rates [146].

Thus slow steaming may require regulation or incentive [144]. A regulated global speed restriction would decrease emissions significantly, but may be unpopular [143], hard to achieve [141, 147] and may even deliver perverse results [144]. Speed reductions via derating engines are covered via the EEDI [148], and may be an option if emissions reduction targets are increased in the future. A bunker levy or broader market-based mechanism may 
be more suitable for giving industry flexibility in achieving reductions specific to each case $[143,147]$.

\subsection{Paints and hull coatings}

A smooth hull is important for efficient operation and minimising fuel consumption. Bacteria attached to the underwater surface of ships attracts larger organisms, such as seaweed, bivalves and mussels (see Figure 11). These increase a ship's drag coefficient, slowing it down and increasing fuel consumption [149-151]. Slime can add 1-2\% to drag, weed adds up to $10 \%$, and the heaviest fouling can increase fuel consumption by $40-50 \%$ [151-153]. The average surface roughness of a typical ship hull increases by $40 \mu \mathrm{m} / \mathrm{year}$, which translates to $1-1.2 \%$ per year increase in fuel consumption [153].

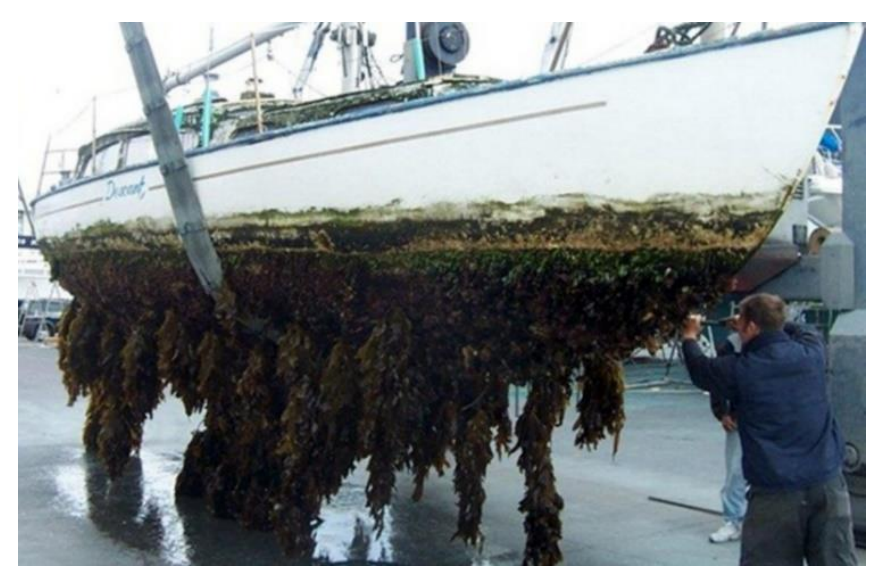

Figure 11: Fouling costs upon the attachment to ship hull which cause serious problems in shipping industry. Reproduced with permission from Editec Group.

Paints and hull coating can minimise the skin friction component of resistance, and significant capital is invested in anti-fouling paints to prevent bacteria from attaching to the hull $[154,155]$. These have anti-corrosion and anti-fouling properties to protect against seawater and marine organisms [156], and have been used for many decades [149, 151].

Tin-based marine coatings were widely used in the 1960-1970s containing tributyltin (TBT) compounds that were detrimental to the environment [149]. The degradation of TBT in the marine environment causes numerous effects, such as endocrine disruption leading to sexual disorders, including imposex in dog whelks [128, 149, 155, 157], leading to international legislation banning their use $[151,158]$.

To date it has not been possible to match TBT coatings in terms of performance, cost and ease of application, but research is ongoing to find ecologically benign alternatives. Modern coatings can be broadly classed as either biocide based [157]:

- Insoluble matrix (epoxy, polyester, vinyl ester); 
- Soluble matrix (self-polishing, ablative, hybrid);

or biocide free:

- Fouling release (silicone elastomers);

- Mechanical cleaning (epoxy/vinyl esters).

Biocides prevent fouling attachment and growth, but may impact upon the environment. Unfortunately, their biocide output is greatest when the ship is at voyage and thus least vulnerable to fouling, causing excessive loss of biocide [157]. Silicone and fouling release technologies are attractive biocide-free alternatives from an environmental perspective [157]. These paints are non-stick to prevent biofouling but are relatively expensive. They also lack the durability of the biocide based systems and are more difficult to apply [153]. However, given their environmental profile, these technologies will become increasingly important for control of marine fouling.

\subsection{Waste Heat Recovery}

Around half of the heat energy produced by the power train is lost as ambient heat without doing any useful work [159, 160]. Waste Heat Recovery Systems (WHRS) can convert heat from the exhaust and coolant into useful mechanical or electrical energy [161], with estimates of fuel savings in the range of $4-16 \%[159,160,162]$. Several technologies are available with a range of efficiencies, notably Steam Rankine Cycle, Organic Rankine Cycle (ORC) and Kalina Cycle. The ORC uses an organic fluid for energy conversion [160] and forms the basis of most small-scale WHRSs due to simplicity, efficiency at low temperature differences, and moderate costs [163]. The Kalina Cycle uses a solution of ammonia and water, with different boiling points, for its working fluid. This allows more heat to be extracted, since boiling occurs over a range of temperatures in distillation [160].

A WHRS represents an additional capital cost but fuel savings may result in payback period of less than 3 years [164], whereas other studies suggest cost-effectiveness across liquid fuel engines as well as gas engines $[165,166]$. However, systems cannot be retrofitted on every vessel, even if they are commercially viable.[164-166]

\subsection{Exhaust treatment}

Exhaust gas treatment is another option to decarbonise, albeit at an early stage of development for $\mathrm{CO}_{2}$. $\mathrm{NO}_{x}$ and $\mathrm{SO}_{x}$ scrubbers are widely used for ships using residual fuels, whilst much work is ongoing to develop methane oxidation catalysts [167-169].

Potential routes exist for carbon capture and storage (CCS) to reduce $\mathrm{CO}_{2}$ emissions from the exhaust. The Calix RECAST design involves scrubbing exhaust gas to capture $85-90 \%$ of the $\mathrm{CO}_{2}$, and using the heat generated in the exothermic reaction to provide additional motive power and increase fuel efficiency [170]. A dry lime scrubber would produce inert 
limestone which could be scattered into the ocean. Any surplus lime remaining in the used sorbent will remove additional carbon from the oceans by converting to calcium bicarbonate, thus reducing ocean acidity $[171,172]$. However, this is likely to be an energyintensive process from a life cycle perspective; low-carbon lime production would be required to deliver emissions reductions rather than simply transferring emissions from one sector to another $[173,174]$. Costs may be significant and more research is required on the localised ecosystem impacts of increased pH [175].

\section{Combined Decarbonisation Potential}

The previous sections have outlined the multitude of technical and operational options to decarbonise international shipping, and uncertainties around the potential of each. This section summarises the carbon mitigation potentials and reveals the opportunity for combinations of fuels and efficiency measures to contribute to the IMO $50 \%$ decarbonisation target. Figure 12 summarises the carbon savings offered by different fuels compared to HFO, and of other options that reduce overall fuel consumption, based on a survey of studies. The figure combines analyses from three industry reports $[20,108,176]$, the earlier sections of this study, and the systematic review from Bouman et al. [20].
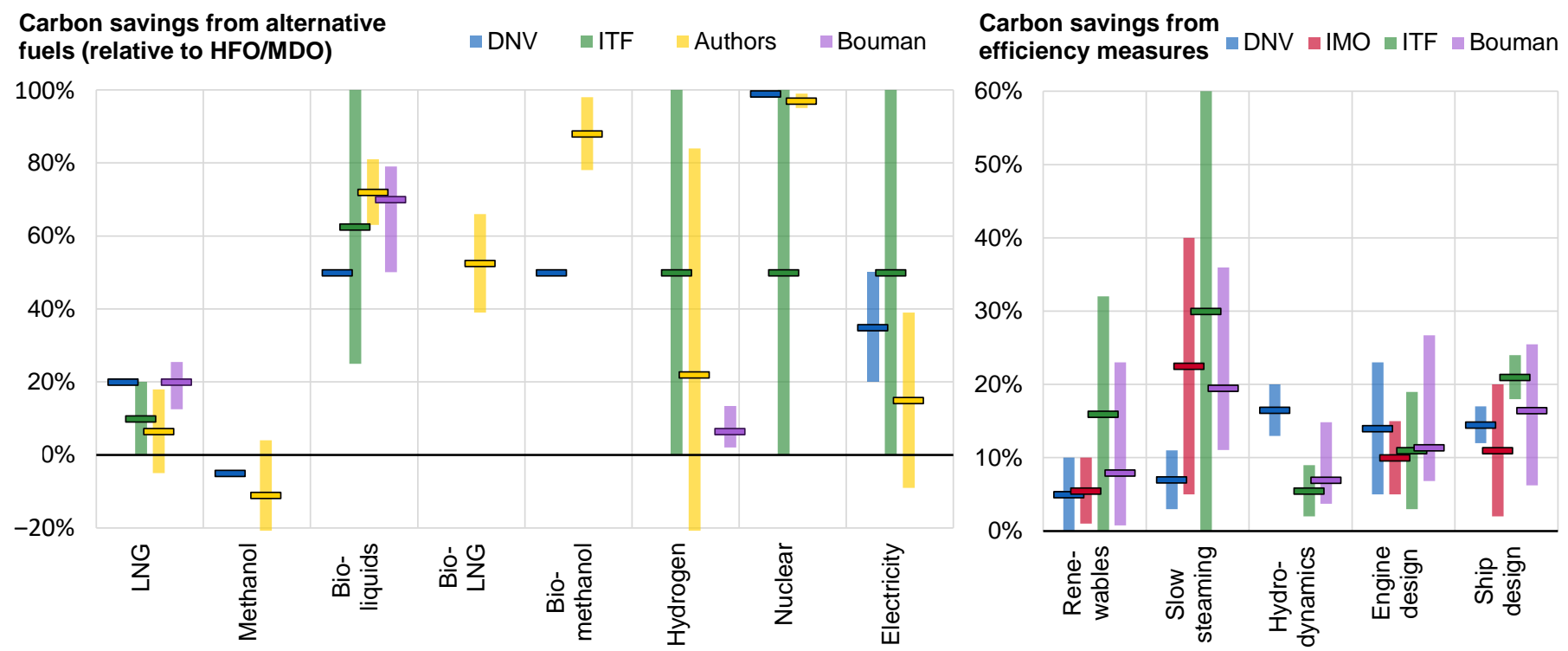

Figure 12. Ranges of GHG emissions reductions via the use of alternative fuels (left panel), and from incorporating various efficiency measures (right panel). Alternative fuels are presented relative to the use of conventional fossil liquid fuels, HFO and MDO. Light bars represent the range from each study $\left(1^{\text {st }} / 3^{\text {rd }}\right.$ quartile from Bouman, $\mathrm{min} / \mathrm{max}$ otherwise), and dark horizontal bars represent the median. Data from $[20,108,176]$. from efficiency measures, with the exception of slow steaming. Particularly, the supposedly 
deeper decarbonisation options from biofuels, hydrogen, nuclear and electric propulsion all range from near complete decarbonisation to negligible difference compared to HFO. This is likely due to their different feedstock supply chains which must be carefully understood prior to being labelled low carbon.

LNG is likely to offer a relatively modest improvement compared to HFO, typically resulting in $10 \%$ reduction in $\mathrm{GHGs}$, but is arguably the most viable short-term solution to reduce $\mathrm{CO}_{2}$ emissions considering cost-effectiveness and available infrastructure. Conventional methanol production from natural gas consistently results in increased emissions compared to HFO, indicating that any methanol fuel must be derived from low carbon sources (e.g. catalytic hydrogenation from renewable hydrogen) if it is to become a decarbonising energy vector. The bio-based fuels (bio-LNG, bio-methanol and bio-diesel) give wide ranges of decarbonisation potential but typically above $70 \%$ reduction whereas the integration of LNG and biofuel technology (bio-LNG) could offer up to $90 \%$ in a reduction of $\mathrm{CO}_{2}$, provided that the bio-LNG supply chain exhibits low environmental and social impacts [177]. Thus, whilst infrastructural costs to implement LNG may be large, the additional incorporation of bioLNG may represent a palatable option both environmentally and economically.

This study estimates that nuclear gives almost $100 \%$ decarbonisation, whereas using grid electricity is dependent on the regional generation mix [108]. This paper's estimate (yellow bar) is based on the principle that ships would recharge in ports, and so calculates the average carbon intensity of electricity at the world's 100 largest ports [178], weighting each port by the shipping volume in 2015 [179]. The weighted average is currently $577 \pm 199$ $\mathrm{gCO}_{2} / \mathrm{kWh}$, but this would fall by $10 \%$ if China were excluded.

Efficiency improvement measures may reduce impacts on average by $5-30 \%$. Moderate efficiency gains may be made by each option, but the largest contributor is via slowsteaming (up to 60\%) [32, 140, 144]. Indeed, it has been highlighted as a critical step in meeting future decarbonisation targets $[28,180]$. The incorporation of wind and solar assistance (up to $32 \%$ ) and improvements in ship design (up to $24 \%$ ) give substantial benefits also. Notably, none of these options are mutually exclusive, either across these options or in conjunction with the fuel options, thus benefits are compounded if combined.

To estimate the combined impact of changing fuels and implementing efficiency measures, this study uses the improvement estimates given in Figure 12 via a Monte Carlo simulation to determine the compounded benefits under different combinations of decarbonising measures. The emissions reductions from each fuel and efficiency option were simplified to a normal distribution with mean and standard deviation taken from all the studies in Figure 12. Each fuel was considered with combinations of the five efficiency measures categorised in Figure 11, sampled across all possible permutations. 
The results are illustrated in Figure 13 which shows the probability of meeting a $50 \%$ and $80 \%$ GHG reduction target compared to HFO by implementing different fuels combined with different efficiency measures (from zero efficiency measures to including all five categories). The error bars represent the minimum and maximum probabilities from the different permutations of options.
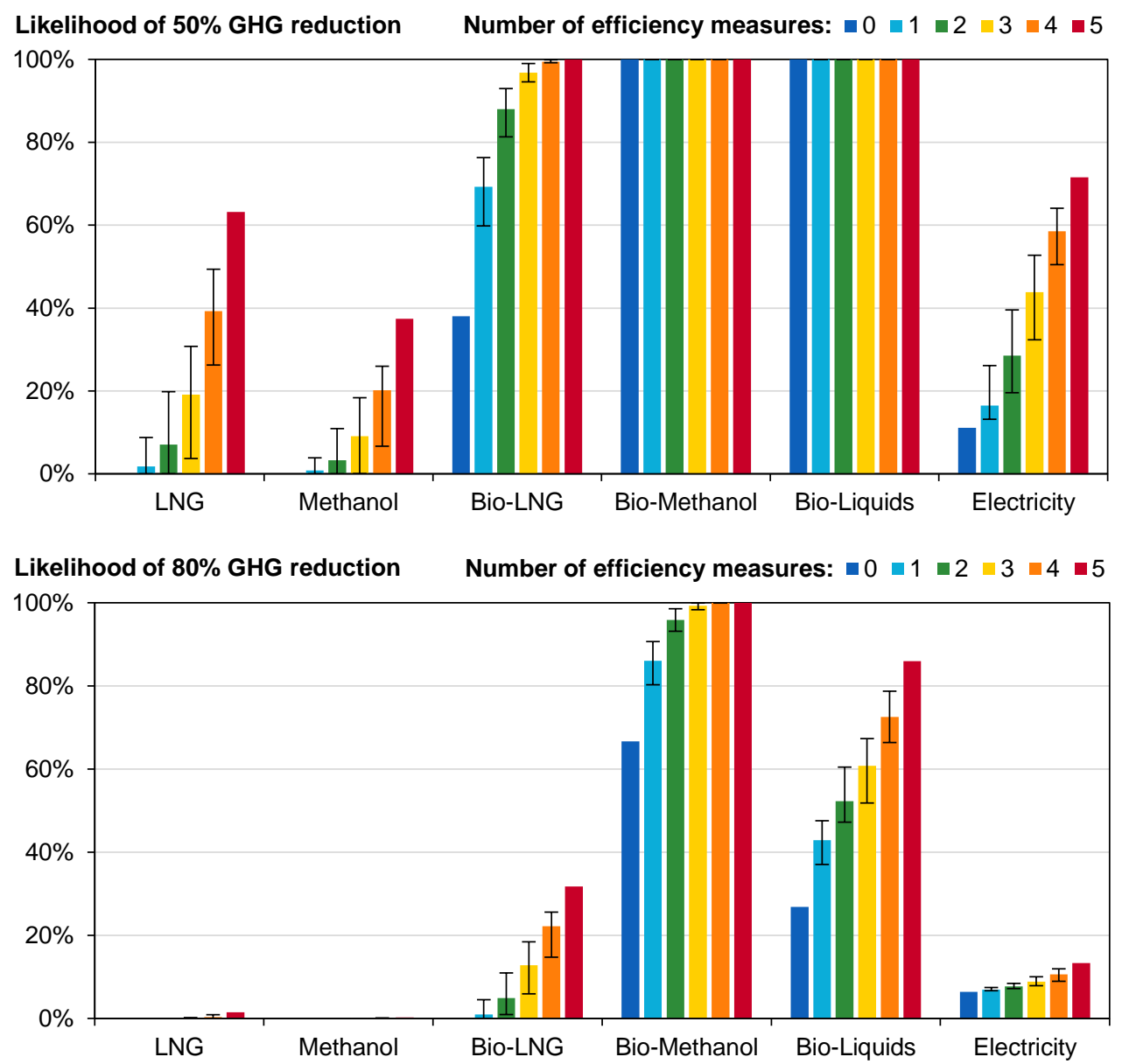

Figure 13. Probability of meeting the $50 \%$ GHG emission reduction target (top) and a stronger $80 \%$ target (bottom) via the use of alternative fuels alongside combinations of

5 different efficiency measures (renewable assisted propulsion, slow steaming,

hydrodynamics, engine design and ship design).

For LNG-fuelled ships to comply with a $50 \%$ GHG reduction compared to HFO, strong efficiency measures are required. To achieve a 50\% likelihood of achieving $50 \%$ reductions with LNG, all efficiency categories must be implemented. The bio-based fuels require little efficiency improvement to meet a 50\% target, although limited bio-resource availability may further incentivise the uptake of efficiency measures to reduce consumption. Further, for the bio-LNG routes, efficiency measures are required to reach climate targets due to the potential presence of methane emissions which have a strong climate impact. 
It must be noted here that this study does not account for the interrelation between efficiency measures here. Particularly the impact of slow steaming on both wind assistance and hydrodynamics. Slower vessel speeds result in an improved contribution from wind assistance, which compounds parallel improvements. However, slower speeds may reduce the impact of some hydrodynamic measures such as hull coatings where higher speeds improve performance. Further work on modelling vessel and fuel improvements would serve to better understand the multiple improvement pathways.

Combined fuel and efficiency improvements are shown to potentially drastically reduce GHG emissions [20], which is corroborated by the IEA's estimate of the contribution to decarbonising international shipping from a selection of measures (Figure 14) [57]. The study suggests the main contributors are efficiency improvements which increase ship capacity and utilization, as well as through vessel and engine design and operational measures. Across the international shipping fleet wind assistance would only contribute up to $15 \%$, whereas switching $50 \%$ of the fleet to advanced biofuels would result in a reduction of $16 \%$.

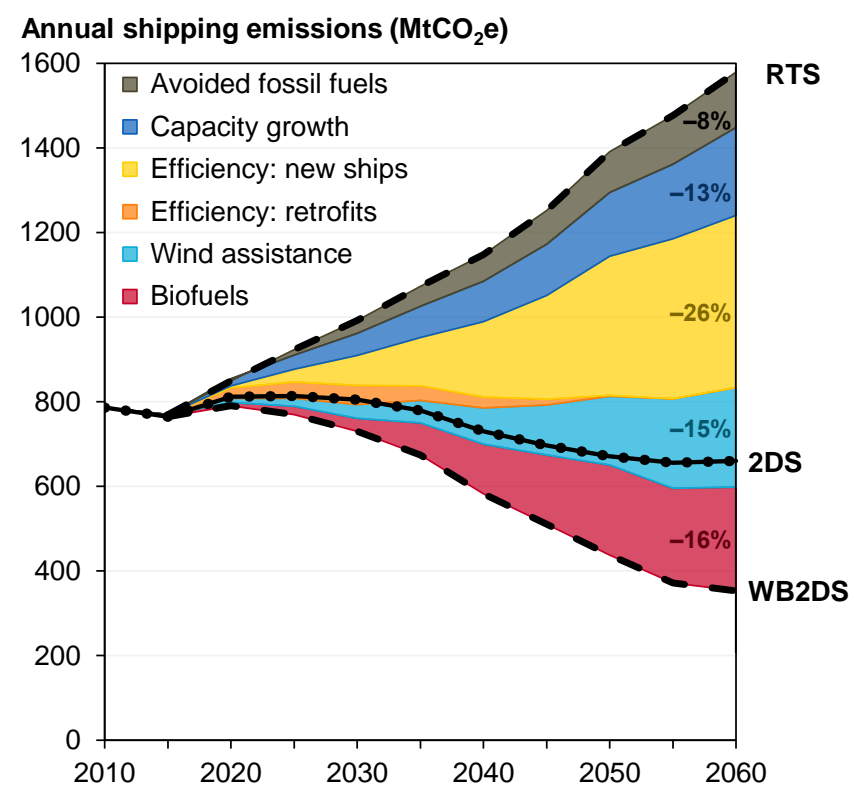

Figure 14. IEA pathway to reduce global shipping emissions by $50 \%$ by 2050 , highlighting the trajectories anticipated in their scenarios: Reference Technology Scenario, two Degree scenario (2DS) and well below two degree scenario (WB2DS). The contribution from the major efficiency and fuel change measures in 2060 are shown inset to the right. Data from [57]

In conclusion, specific technological and operational measures that would meet the decarbonisation requirements of the maritime industry could be met via combinations of several pathways. This would certainly be achievable with a new fleet with globally supportive legislations and policies, but the current fleet may require costly retro-fitting 
mechanisms to enable said solutions. Ultimately, a combination of technology, fuels and operational measures must be enabled by effective, globally enforced policies.

\section{Decarbonisation policies}

Given that the EEDI and SEEMP are likely to make only a modest impact on reducing GHG emissions alongside projected industrial growth to 2050 [181], stronger policy measures are required to meet emerging carbon targets. Potential policies include stronger efficiency targets, speed limits, fuel-standards or broader market-based mechanisms [182]. The broad options for decarbonisation are covered in the following section, followed by discussion of existing mechanism proposals and an analysis of the pros and cons of these options.

\subsection{Policy options to decarbonise shipping}

Policy options can be divided in three categories:

1. The emissions price control approach, in which the participant reacts to a charge or fluctuation in price (that is linked to emissions) [183]. This includes:

(a) environmental taxes, fees, or charges;

(b) charges "en route"; and

(c) environmentally differentiated port or fairway dues.

2. The emissions quantity control approach, where the participants abide by emissions limits or the right to emit and allow trading of these "quantities". This includes:
(a) credit programs;
(b) benchmarking programs; and
(c) cap-and-trade programs.

3. Subsidies, where funding is made available for qualifying decarbonisation measures.

\subsubsection{Emissions price controls}

A tax placed on the purchase of fuel at the point of sale may be an effective route for reduction of emissions from shipping [29], where environmental charges are based on the quantity and/or quality of the pollutant(s) [29, 184]. The US state of Washington has imposed an environmental fuel tax on marine fuels to encourage improvements of the state's waterways. However, there is a risk this method failing from its vulnerability to 'carbon leakage', which is defined as the increase in emissions outside a region as a direct result of a policy to cap emissions within the region [185]. By taking fuel on board from areas outside of where the tax is enforced, the operator of the ship can avoid paying the tax $[29,186]$. 
Unlike environmental charges, a price set "en route" would be determined by the emission rates, as opposed to fuel quantities. Closely echoing the en route policy already established in the aviation sector for many years, this approach may be highly applicable to maritime shipping.

\subsubsection{Emissions quantity controls}

Credit-based trading programs provide operators with credits to manage their emissions to meet a required level [183]. This may be an extension of established cap-and-trade programs, allowing operations from different sectors of the market to join an existing trading program. However, credits should only be provided to measures that reduce emissions substantially below a certain level and may require regular evaluation as technologies, operations and efficiencies change. A trade-off exists between creating incentives high enough to motivate ship-owners to participate (given the scheme is voluntary) but not so high that credits are awarded to projects with limited additional contribution to decarbonisation.

Benchmarking trading programmes sets an average emissions level that cannot be exceeded [183]. These are typically flexible in nature, where such schemes inherently engage in offsetting as opposed to elimination of emissions, thus it is imperative that an appropriate benchmark is set to enable effective overall emission reductions $[29,187]$.

A cap-and-trade program creates a total aggregated cap on emissions. Allowances are allocated to emitters and once regulators have fixed a cap, every emitter is free to trade. Similar to benchmarking programs, it may be more cost-effective for emitters to invest in emissions reductions technologies instead of purchasing allowances.

\subsubsection{Subsidies}

Subsidies may be delivered through various mechanisms to provide direct financial support to industry sectors from either the government, or in the case of shipping, maritime authorities. Subsidy mechanisms include grants, low-interest loans, favourable tax treatment, tendering systems, and other financial assistance for products with desirable environmental characteristics [188]. For example, Transport Canada offers subsidies under its Freight Technology Incentives Program which aims to lower GHG emissions output by reducing fuel consumption and encouraging the employment of energy efficient technologies [29]. Another example was the Port of Hamburg, which for a limited period offered publicly funded discounts to port dues to ships fulfilling certain emissions criteria [188].

\subsection{Market based mechanism proposals}

By 2010, several proposals from various member states had been submitted to the 
Maritime Environment Protection Committee (MEPC), aligned with IMO principles [189]. Norway recommended a sector-wide cap on net emissions from international shipping and a trading system alongside this, which suggested exemptions should be made for voyages to Small Island Developing States (SIDS). France provided a similar proposal, but also targeted auction design. The UK suggested that the ETS proposal employ a two-phase approach, with the initial phase being one where emissions are offset [190].

Under the proposed US Ship Efficiency and Credit Trading, instead of a cap on emissions or a surcharge on fuel, all ships would be subject to mandatory energy efficiency standards, enforced via an efficiency-credit trading programme [191]. Similar to the EEDI, it sets efficiency standards for both new and existing ships which remain committed to reduction from the established baseline [191]. Japan and the World Shipping Council (WSC) have proposed efficiency-targeted standards as opposed to an ETS or bunker levy favoured in other countries. The Energy Incentive Scheme (EIS) sets a standard that also mirrors the EEDI baseline, and administers supplementary costs to ship-owners, operators or consumers in line with the amount of fuel consumed for non-compliance. The International Union for Conservation of Nature (IUCN) proposes to compensate developing countries for the potential financial impact of an MBM via eligibility to rebate mechanisms.

Since 2010, the EU have legislated that shipping will be brought into the EU-ETS by 2023 in the absence of action from the IMO by 2021 [181]. Any ships that arrive at EU ports would need to comply to this legislation. It may be that this action provides a catalyst for a globally applicable shipping ETS.

\subsection{Assessment of policy options}

These main policy options are discussed below in terms of the main advantages and disadvantages, and are summarised in Table 3.

Table 3: The merits of different shipping decarbonisation policy options

\begin{tabular}{|c|c|c|}
\hline & Advantages & Disadvantages \\
\hline $\begin{array}{l}\text { Emissions price } \\
\text { controls }\end{array}$ & $\begin{array}{l}\text { - Economic efficiency } \\
\text { - Environmental efficiency }{ }^{1}\end{array}$ & $\begin{array}{l}\text { - } \text { Carbon leakage } \\
\text { - Cap on development } \\
\text { - } \text { Displacement to air or road }\end{array}$ \\
\hline Emissions quality & - Flexibility & - Transaction costs \\
\hline controls & - Economic efficiency & $\begin{array}{l}\text { - Burden of additional costs on developing } \\
\text { countries }\end{array}$ \\
\hline Subsidies & - Can be targeted & $\begin{array}{l}\text { - Requires careful implementation and oversight } \\
\text { - Need for revision when conditions change }\end{array}$ \\
\hline
\end{tabular}

\footnotetext{
${ }^{1}$ Environmental efficiency can be defined as an efficiency measure that accounts for both economic and environmental factors [192] M.-L. Song, Y. Guan, F. Song. Environmental efficiency, advances in environmental technology and total factor of environmental productivity of China. Kybernetes. 42 (2013) 943-54.
} 
A carbon tax represents high economic and environmental efficiency in theory, but may result in a cap on development, and potentially a shift away from marine to higher-carbon transport routes (aviation and road). A disadvantage of price-control approaches is the risk of carbon leakage. Although nation states may initiate a taxation system, a ship remains a territorial extension of a country whose flag it flies and jurisdiction it will be under. However, ships are able to change this legal jurisdiction and register to flags of convenience with better tax rates, lower compliance to safety, and potentially less liability to carbon regulation [193]. To negate evasions and competitive distortions, it is vital that marketbased measures for maritime transport are globally applied [194].

A quantity control mechanism such as an ETS has two key benefits. Firstly, its flexible nature enables the cap to vary, but gives certainty on the emissions reductions achieved. Due to the highly cyclical nature of the industry, a variation in the demand for allowances influences the price of emissions therefore it is essential to set an appropriate cap. Secondly, it may be cost-efficient in comparison to the 'charging' alternatives, producing an environmental benefit at least cost.

The deployment of a marine emission-trading scheme (METS) presents several challenges. A cap-and-trade policy can confront participants and regulators with high transaction costs related to trading, monitoring, enforcement, and verification. The volume of allowances traded may be lower with higher transactions costs, resulting in sub-optimal trading [195]. The economic impacts may add a higher burden to developing countries than to developed countries. A mitigation of this disparity may be to apply a "common but differentiated responsibility" principle in the international shipping sector [27]. This can be resolved through the employment of an agreed rebate mechanism, in which developing countries could recover the costs.

Credits are pre-certified and approved before they are released for trading, which helps to reduce the risk of carbon leakage among members. Other variables to monitor include ship location, emissions factors, activity and energy consumption. Ship-owners may save allowances when mitigation is cheaper, to utilise for the future when high reduction costs arise, moderating the effect of price volatility on the ETS. However, there is a risk that borrowing against credits may result in firms simply offsetting emissions rather than actually reducing them. Thus, if a maritime ETS were to be implemented, borrowing may need to be restricted by quantity or time limits [196].

Providing direct financial support through subsidy has been very effective in other sectors, can move swiftly, and can target technologies or interventions [197]. In addition there are several examples of subsidies in the shipping sector that might guide future policy development $[183,188]$. However, subsidies must be carefully implemented and monitored, 
and revised where conditions change, as seen in other targeted support mechanisms such as feed-in tariffs in the electricity generation sector [197].

In conclusion, a range of policy options exist to drive decarbonisation in the shipping sector. A maritime ETS has the potential to provide cost-efficient emissions reductions, but must be designed accordingly with respect to auditing processes. The flexible nature of a METS will allow for individual ship-owners to employ their own choice of measures as opposed to a taxation scheme. To address the capital cost of mitigation options, subsidy schemes such as differentiated port dues and incentive schemes could be employed to accelerate the lowcarbon transition. Administrative costs could unfairly burden some countries, but could be prevented by a rebate system where ETS revenues are partly re-distributed amongst developing countries as well as towards climate change funds. Lastly, carbon leakage risks eliminating the potential benefits of METS and requires stringent regulation through independent external bodies. However, some have argued that implementing a marketbased mechanism is unlikely in the short term, and should be examined as a longer-term option [27].

\section{Conclusion}

This study reviewed the potential for a multitude of options to decarbonise international shipping, including fuels, energy efficiency technologies, operations and policies. There is no single route to fully decarbonising the maritime industry, so a multifaceted response is required. While rooted within a complex international regulatory framework, decarbonisation could be supported by long-term, consistent and effective policy to enable the industry to effectively reduce emissions.

Liquified natural gas (LNG) is the main alternative to marine diesel and heavy fuel oil (MDO and $\mathrm{HFO}$ ), and could provide a cost-effective reduction in $\mathrm{CO}_{2}$ emissions whilst meeting $\mathrm{SO}_{\mathrm{x}}$ and $\mathrm{NO}_{\mathrm{x}}$ emissions regulations. However, the greenhouse gas $(\mathrm{GHG})$ benefit is reduced by methane slip, with an overall reduction of $8-20 \%$ compared to HFO and MDO. LNG is currently cheaper than the incumbent marine fuels, but infrastructure must be expanded to increase market share. LNG cannot be used in isolation to meet a $50 \%$ reduction in GHG emissions, but must be combined with efficiency measures such as slow steaming, wind assistance, or even blended with bio-LNG.

Biofuels have great potential as a renewable source of energy and would be most commercially viable when used in conjunction with other liquid or gaseous based fuels. However, emissions, costs and applicability vary widely across different biofuels and the long-term ramifications of a dependency on biofuels for transport could be ultimately detrimental to achieving a sustainable industry. 
Due to the emissions profile and flexibility of hydrogen as a fuel, the potential to reduce emissions in shipping and enable renewable industries is high, for example by utilising onshore nuclear and renewable power generation to store hydrogen. The capital-intensive infrastructure requirements may leave hydrogen as a longer-term solution, but it may be more economically feasible to initially select a specific large vessels (e.g. tankers) and 'point to point' routes to be hydrogen fuelled, minimising infrastructural requirements. Nuclear propulsion could almost completely decarbonise shipping and is suitable for vessels that require a high-density energy source with long journeys, but safety and security concerns are likely to persist as the main barrier for commercial shipping. Renewable sources of energy such as solar and wind have potential to increase the efficiency of vessels and assist propulsion, thus reducing fuel consumption. With developing energy storage technologies and improved designs small ships, there may be a fleet in the future able to run on very little conventional fuel.

Even with conventional fuels, various efficiency measures can offer significant decarbonisation potential. Slow-steaming reduces fuel consumption and $\mathrm{CO}_{2}$ emissions by $20-30 \%$, and up to $60 \%$ at the extreme. Longer voyage time may result in higher inventory costs and may need to be financed and insured for a longer period of time, but can improve reliability of scheduling. Antifouling paints can be used as a barrier against biofouling and reduce drag, but further work is needed to quantify the cost-benefit and potential contribution to reducing emissions from the fleet. Waste heat recovery from ship drivetrains may achieve fuel savings of around $4-16 \%$.

There is evidently a cost-emission trade-off, where the most cost effective options such as LNG currently only offer modest improvements in GHG emissions. A balance between costeffective fuels and improved efficiency measures is essential in minimising costs. To achieve a $50 \%$ likelihood of achieving $50 \%$ GHG reductions with LNG-fuelled ships, all five categories of efficiency measures must be implemented together. The bio-based fuels however require little efficiency improvement to meet a 50\% target, although limited bio-resource availability and complications in ensuring sustainability across the full fuel life-cycle may further incentivise the uptake of efficiency measures to reduce consumption.

With a growing maritime sector, applying a cap on global shipping emissions would ensure this growth is re-routed towards sustainable pathways. A credit-trading based mechanism would provide flexibility (appeasing maritime agents) and give room for industry to develop and select from various options. The revenue generated from credit-based approaches can contribute to investments such as further research in climate change projects, funding infrastructure necessary for LNG and other alternative fuels, and compensating developing countries that are unfairly burdened by a cap. However, most important to the maritime sector, these revenues can fund the subsidies and incentives required for emissions 
reductions and increasing efficiencies. Stringent regulation will be required to limit the risk of carbon leakage.

Ultimately, it is essential that the route to decarbonisation incorporates a combination of fuels, technology and policy and that the various combinations of each cater to both shortterm and long-term approaches. With LNG being economically feasible, technologically secure and guaranteeing environmental benefits in the short term, a combination of subsidies and port dues can effectively accelerate its implementation. However, further consideration is still needed to drive the use of nuclear, renewables and hydrogen in the long term. Both approaches can be complimented by energy efficiency schemes, both technology- and policy-related; however, it is vital that an overarching policy be introduced in the short-term to drive the rapid and equitable decarbonisation that this important sector vitally needs.

Funding for the Sustainable Gas Institute is gratefully received from Royal Dutch Shell, Enagás SA, and from the Newton/NERC/FAPESP Sustainable Gas Futures project NE/N018656/1. Funding through the EPSRC project EP/R045518/1 is gratefully acknowledged. Note that funding bodies were not involved in the design, implementation or reporting of this study.

\section{References}

[1] A. Miola, B. Ciuffo. Estimating air emissions from ships: Meta-analysis of modelling approaches and available data sources. Atmospheric environment. 45 (2011) 2242-51.

[2] Maersk. Maersk sets net zero co2 emission target by 2050. in: A.P. Moller, (Ed.).2018.

1070 [3] $\varnothing$. Buhaug, J. Corbett, $\varnothing$. Endresen, V. Eyring, J. Faber, S. Hanayama, et al. Second IMO GHG study 2009. International Maritime Organization, London, 2009.

[4] UNCTAD. United Nations conference on trade and development. Review of Maritime Transport. (2014).

[5] J. Hoffmann, S. Kumar. Globalisation-the maritime nexus. in: C.T.H. Grammenos, (Ed.). The Handbook of Maritime Economics and Business. Lloyd's List, London, 2010.

[6] J. Lister, R.T. Poulsen, S. Ponte. Orchestrating transnational environmental governance in maritime shipping. Global Environmental Change. 34 (2015) 185-95.

[7] IMO. EEDI - rational, safe and effective. International Maritime Organization, London, 2012.

1080 [8] International Energy Agency. Energy Technology Perspectives. OECD/IEA, Paris, 2017.

[9] World Resources Institute. CAIT - Historical Emissions Data. 2017.

[10] IMO. Adoption of the initial IMO strategy on reduction of GHG emissions from ships and existing IMO activity related to reducing GHG emissions in the shipping sector. Note by 
the International Maritime Organization to the UNFCCC Talanoa Dialogue. International Maritime Organization, London, UK, 2018. pp. 1-27.

[11] UNCTAD. Review of Maritime Transport. 2017.

[12] Shell. Sky Scenario. 2018.

[13] US Energy Information Administration. International Energy Outlook 2016. 2016.

[14] US Energy Information Administration. US Natural Gas Imports by Country. 2018.

1090 [15] MEPC. Resolution MEPC.176(58): Amendments to the annex of the Protocol of 1997 to amend the international convention for the prevention of pollution from ships, 1973, as modified by the protocol of 1978 relating thereto (Revised MARPOL Annex VI) in MEPC 58/23/Add.1 in: I.M. Organization, (Ed.). 2008.

[16] European Commission. Reducing emissions from the shipping sector. 2018.

1095 [17] IBIA. Test data for 2017 show limited share of low sulphur residual fuels. in: IMO, (Ed.). The International Bunker Industry Association, 2018.

[18] D. Lowell, H. Wang, N. Lutsey. Assessment of the fuel cycle impact of liquefied natural gas as used in international shipping. in: International Council on Clean Transportation (2013).

1100 [19] M.S. Eide, C. Chryssakis, $\varnothing$. Endresen. CO2 abatement potential towards 2050 for shipping, including alternative fuels. Carbon Management. 4 (2013) 275-89.

[20] E.A. Bouman, E. Lindstad, A.I. Rialland, A.H. Strømman. State-of-the-art technologies, measures, and potential for reducing GHG emissions from shipping - A review. Transportation Research Part D: Transport and Environment. 52 (2017) 408-21.

1105 [21] J. Faber, H. Wang, D. Nelissen, B. Russell, D.S. Amand. Reduction of GHG emissions from ships: Marginal Abatement Costs and Cost Effectiveness of Energy-Efficiency Measures. in: SNAME, (Ed.). International Maritime Organization (IMO), London, UK, 2011.

[22] P. Gilbert, C. Walsh, M. Traut, U. Kesieme, K. Pazouki, A. Murphy. Assessment of full life-cycle air emissions of alternative shipping fuels. Journal of Cleaner Production. 172 (2018) 855-66.

[23] International Transport Forum. Decarbonising Maritime Transport: Pathways to zerocarbon shipping by 2035. Case-specific policy analysis. International Transport Forum, 2018. pp. 1-86.

[24] J. Yuan, S.H. Ng, W.S. Sou. Uncertainty quantification of $\mathrm{CO} 2$ emission reduction for maritime shipping. Energy Policy. 88 (2016) 113-30.

[25] H. Lindstad, R. Verbeek, M. Blok, S.v. Zyl, A. Hübscher, H. Kramer, et al. GHG emission reduction potential of EU-related maritime transport and on its impacts. TNO, Delft, The Netherlands, 2014. pp. 1-130.

[26] T. Smith, C. Raucci, S.H. Hosseinloo, I. Rojon, J. Calleya, S.S.D.L. Fuente, et al. CO2 Emissions from International Shipping: Possible reduction targets and their associated pathways. UMAS, London, UK, 2016. pp. 1-61.

[27] Y. Shi. Reducing greenhouse gas emissions from international shipping: Is it time to consider market-based measures? Marine Policy. 64 (2016) 123-34.

[28] Z. Wan, A. el Makhloufi, Y. Chen, J. Tang. Decarbonizing the international shipping industry: Solutions and policy recommendations. Marine Pollution Bulletin. 126 (2018) 42835.

[29] G. Nikolakaki. Economic incentives for maritime shipping relating to climate protection. WMU Journal of Maritime Affairs. 12 (2012) 17-39.

[30] Marine Flottenkommando. Number of ships in the world merchant fleet between January 1, 2008 and January 1, 2017, by type. Statistica, 2018. 
[31] R. Green, I. Staffell. Electricity in Europe: exiting fossil fuels? Oxford Review of Economic Policy. 32 (2016) 282-303.

[32] T.W.P. Smith, J.P. Jalkanen, B.A. Anderson, J.J. Corbett, J. Faber, S. Hanayama, et al. Third IMO GHG Study. International Maritime Organization, London, 2015. pp. 1-327.

[33] World Bank. World Development Indicators. 2018.

[34] B.S. Halpern, M. Frazier, J. Potapenko, K.S. Casey, K. Koenig, C. Longo, et al. Spatial and temporal changes in cumulative human impacts on the world's ocean. Nature Communications. 6 (2015) 7615.

[35] N. Olmer, B. Comer, B. Roy, X. Mao, D. Rutherford. Greenhouse Gas Emissions From 1140 Global Shipping, 2013-2015. in: ICCT, (Ed.). The International Council on Clean Transportation, 2017. pp. 1-38.

[36] C. Wang, J.J. Corbett. The costs and benefits of reducing SO2 emissions from ships in the US West Coastal waters. Transportation Research Part D: Transport and Environment. 12 (2007) 577-88.

1145 [37] C. Deniz, B. Zincir. Environmental and economical assessment of alternative marine fuels. Journal of Cleaner Production. 113 (2016) 438-49.

[38] L. Jiang, J. Kronbak, L.P. Christensen. The costs and benefits of sulphur reduction measures: Sulphur scrubbers versus marine gas oil. Emission Control Areas and their Impact on Maritime Transport. 28 (2014) 19-27.

1150 [39] J. Vidal. Health risks of shipping pollution have been 'underestimated'. Environment, Pollution. The Guardian, 2009.

[40] G. Myhre, D. Shindell, F.-M. Bréon, W. Collins, J. Fuglestvedt, J. Huang, et al. Anthropogenic and Natural Radiative Forcing. in: T.F. Stocker, D. Qin, G.-K. Plattner, M. Tignor, S.K. Allen, J. Boschung, A. Nauels, Y. Xia, V. Bex and P.M. Midgley (eds.), (Ed.). In:

1155 Climate Change 2013: The Physical Science Basis Contribution of Working Group I to the Fifth Assessment Report of the Intergovernmental Panel on Climate Change. Cambridge University Press, Cambridge, United Kingdom and New York, NY, USA, 2013.

[41] IMO. Third IMO GHG Study 2014 - Executive Summary and Final Report. 1 ed. International Maritime Organization, London, UK, 2015. pp. 1-327.

1160 [42] DNV GL Maritime. Methanol as marine fuel: Environmental benefits, technology readiness, and economic feasibility. in: I.M. Organization, (Ed.).2016.

[43] J.N. Cape, M. Coyle, P. Dumitrean. The atmospheric lifetime of black carbon. Atmospheric Environment. 59 (2012) 256-63.

[44] B. Comer, N. Olmer, X. Mao, B. Roy, D. Rutherford. Black carbon emissions and fuel use in global shipping, 2015. International Council on Clean Transportation (ICCT), Washington, DC, 2017.

[45] IMO. Brief History of IMO. International Maritime Organization, London, 2017.

[46] Fast Offshore. Ship Registration - Fast Offshore. Overseas Business Services Ltd, www.fastoffshore.com.2017.

1170 [47] International Chamber of Shipping. Shipping Industry Flag State Performance Table 2016/2017. London, 2017.

[48] DNV GL Maritime. Upcoming environmental regulations for emissions to air - IMO NOx Tier III. 2015.

[49] M. Doudnikoff, R. Lacoste. Effect of a speed reduction of containerships in response to 1175 higher energy costs in Sulphur Emission Control Areas. Transportation Research Part D: Transport and Environment. 28 (2014) 51-61. 
[50] M. Rozmarynowska, B. Ołdakowski. Implications of new regulation regarding sulphur content in ship's fuel on maritime transport sector within Baltic Sea Region. TransBaltic project ed. Baltic Ports Organization Secretariat, Helsinki, Finland, 2012.

1180 [51] IMO. Prevention of Air Pollution from Ships. International Maritime Organization, London, 2017.

[52] W. Todts. Air Pollution from ships. 2017.

[53] O. Schinas, M. Butler. Feasibility and commercial considerations of LNG-fueled ships. Ocean Engineering. 122 (2016) 84-96.

1185 [54] International Council on Clean Transportation. The Energy Efficiency Design Index (EEDI) for New Ships. 2011.

[55] L. Stevens, C. Sys, T. Vanelslander, E. van Hassel. Is new emission legislation stimulating the implementation of sustainable and energy-efficient maritime technologies? Research in Transportation Business \& Management. 17 (2015) 14-25.

1190 [56] D. Rutherford, B. Comer. The International Maritime Organization's Initial Greenhouse Gas Strategy. The International Council on Clean Transportation (ICCT), Accessed from: www.theicct.org/sites/default/files/publications/IMO\%20GHG\%20strategy\%20rapid\%20ana lysis\%20vf.pdf, 2018. pp. 1-8.

[57] IEA. Energy Technology Perspectives 2017. in: I.E. Agency, (Ed.). OECD/IEA, Paris, 2017. 1195 pp. 1-443.

[58] A. Bernatik, P. Senovsky, M. Pitt. LNG as a potential alternative fuel - Safety and security of storage facilities. Journal of Loss Prevention in the Process Industries. 24 (2011) 19-24.

[59] D. Stenersen, O. Thonstad. GHG and NOx emissions from gas fuelled engines. Mapping, verification, reduction technologies. SINTEF Ocean AS, Trondheim, Norway, 2017. pp. 1-52.

[60] F. Burel, R. Taccani, N. Zuliani. Improving sustainability of maritime transport through utilization of Liquefied Natural Gas (LNG) for propulsion. Energy. 57 (2013) 412-20.

[61] S. Jafarzadeh, N. Paltrinieri, I.B. Utne, H. Ellingsen. LNG-fuelled fishing vessels: A systems engineering approach. Transportation Research Part D: Transport and Environment. 50 (2017) 202-22.

[62] T. Wilson, D. Turaga. Drivers for LNG Fueled Marine Vessels Vary by Region. ADI Analytics, 2015.

[63] A.B. Smith. Gas fuelled ships: fundamentals, benefits classification \& operational issues. Proceedings of the first gas fuelled ships conference, Hamburg, Germany, 2010.

1210 [64] S. Wang, T. Notteboom. The adoption of liquefied natural gas as a ship fuel: A systematic review of perspectives and challenges. Transport Reviews. 34 (2014) 749-74.

[65] P. Balcombe, N.P. Brandon, A.D. Hawkes. Characterising the distribution of methane and carbon dioxide emissions from the natural gas supply chain. Journal of Cleaner Production. 172 (2018) 2019-32.

1215 [66] R.A. Alvarez, D. Zavala-Araiza, D.R. Lyon, D.T. Allen, Z.R. Barkley, A.R. Brandt, et al. Assessment of methane emissions from the U.S. oil and gas supply chain. Science. (2018).

[67] O. Schuller, B. Reuter, J. Hengstler, S. Whitehouse, L. Zeitzen. Greenhouse Gas Intensity of Natural Gas. Thinkstep AG, Natural \& Bio Gas Vehicle Association (NGVA) Europe, 2017. p. 180.

1220 [68] R. Verbeek, G. Kadijk, P.v. Mensch, C. Wulffers, B.v.d. Beemt, F. Fraga. Environmental and Economic Aspects of Using LNG as a Fuel for Shipping in The Netherlands. TNO, Delft, The Netherlands, 2011. pp. 1-48. 
[69] S. Bengtsson, K. Andersson, E. Fridell. A comparative life cycle assessment of marine fuels liquefied natural gas and three other fossil fuels. Proceedings of the Institution of Mechanical Engineers, Part M: Journal of Engineering for the Maritime Environment. 225 (2011) 97-110.

[70] P. Balcombe, K. Anderson, J. Speirs, N. Brandon, A. Hawkes. The Natural Gas Supply Chain: The Importance of Methane and Carbon Dioxide Emissions. ACS Sustainable Chemistry \& Engineering. 5 (2017) 3-20.

1230 [71] S. Bengtsson, K. Andersson, E. Fridell. A comparative life cycle assessment of marine fuels: liquefied natural gas and three other fossil fuels. Proceedings of the Institution of Mechanical Engineers Part M-Journal of Engineering for the Maritime Environment, 2011. pp. 97-110.

[72] J. Cofala, M. Amann, C. Heyes, F. Wagner, Z. Klimont, M. Posch, et al. Analysis of policy measures to reduce ship emissions in the context of the revision of the national emissions ceilings directive. (2007).

[73] I. Ohashi. Dual-Fuel Marine Engine (Highly Reliable Environmentally Friendly Engine). YANMAR Technical Review. (2015).

[74] J. Algell, A. Bakosch, B. Forsman. Feasibility Study on LNG Fuelled Short Sea and Coastal Shipping in the Wider Caribbean Region. (2012).

[75] MAN Diesel \& Turbo. Costs and Benefits of LNG as Ship Fuel for Container Vessels. MAN Diesel \& Turbo, Copenhagen, Denmark, 2012. pp. 1-18.

[76] Ship \& Bunker. World Bunker Prices. 2018.

[77] Bunker Index. Bunker Index MDO, BIX MDO. Southport, UK, 2018.

1245 [78] DNV GL Maritime. Current Price Development of Oil and Gas. Norway, 2018.

[79] M. Alvorado. Presentation: Methanol. in: IHS, (Ed.). his, 2016. pp. 1-34.

[80] Intratec. Methanol Price History \& Forecast. Historical Prices in USA, Netherlands, China, India \& Forecast. Houston, Texas, 2018.

[81] Methanex. Methanex Monthly Average Regional Posted Contract Price History. Methanex Corporation, Accessed from: www.methanex.com/our-business/pricing, 2018.

[82] M. Baumgart, J. Olsen. LNG-fuelled Vessels in the Norway Short-Sea Market; A CostEffective Response to Environmental Regulation (Published Master Thesis). University of BergenNorway. (2010).

[83] F. Adamchak. LNG as marine fuel. Gas Technology Institute 17th International conference, 2013.

[84] S. Brynolf, E. Fridell, K. Andersson. Environmental assessment of marine fuels: liquefied natural gas, liquefied biogas, methanol and bio-methanol. Journal of Cleaner Production. 74 (2014) 86-95.

[85] P. Balcombe, J.F. Speirs, N. Brandon, A. Hawkes. Methane emissions: choosing the right

1260 climate metric and time horizon. Environmental Science: Processes \& Impacts. (2018).

[86] A. Florentinus, C. Hamelinck, A. van den Bos, R. Winkel, M. Cuijpers. Potential of Biofuels for Shipping - Final Report. Project number: BIONL11332 ed. Ecofys, European Maritime Safety Agency (EMSA), Utrecht, Netherlands, 2012.

[87] L. Wei, R. Cheng, H. Mao, P. Geng, Y. Zhang, K. You. Combustion process and NOx emissions of a marine auxiliary diesel engine fuelled with waste cooking oil biodiesel blends. Energy. 144 (2018) 73-80.

[88] IEA. Biofuels for the marine shipping sector. An overview and analysis of sector infrastructure, fuel technologies and regulations. IEA Bioenergy, 2017. 
[89] EC. Directive 2009/28/EC of the European Parliament and of the Council, of 23 April 2009 on the promotion of the use of energy from renewable sources and amending and subsequently repealing Directives 2001/77/EC and 2003/30/EC. in: Official Journal of the European Union, 2009.

[90] Maritime Knowledge Center, TNO, TU Delft. Methanol as an alternative fuel for vessels. 2018.

1275 [91] A. Stephenson, D. MacKay. Life Cycle Impacts of Biomass Electricity in 2020. in: Department of Energy and Climate Change, (Ed.).2014.

[92] R. Matthews, N. Mortimer, J.P. Lesschen, T.J. Lindroos, L. Sokka, A. Morris, et al. Carbon impacts of biomass consumed in the EU: quantitative assessment. The Reseach Agency of The Forestry Commission (2015).

1280 [93] R. Slade, A. Bauen, R. Gross. The Global Bioenergy Resource. Nature Climate Change. 4 (2014).

[94] P. Riddell. Nexus Trade-Offs and Strategies for Addressing the Water, Energy and Food Security Nexus in Africa. 1st ed. IWA/IUCN/ICA, Geneva, 2015.

[95] J. Andrews, B. Shabani. Where does hydrogen fit in a sustainable energy economy? Procedia engineering. 49 (2012) 15-25.

[96] D. Argyros, C. Raucci, N. Sabio, T. Smith. Global Marine Fuel Trends 2030. Lloyd's Register Group Limited, University College London Energy Institute, London, 2014.

[97] Methanex. Industry welcomes four new ocean-going vessels capable of running on methanol. 2018.

1290 [98] ETIP Bioenergy. Biofuels In Shipping - Potential Of Biodiesel, Biomethane, Methanol And SOFC Technology For Ships. Biofuelstp.eu, 2016.

[99] I. Staffell, D. Scamman, A.V. Abad, P. Balcombe, P.E. Dodds, P. Ekins, et al. The role of hydrogen and fuel cells in the global energy system. Energy \& Environmental Science. In press: DOI: 10.1039/C8EE01157E (2018).

1295 [100] J. Speirs, P. Balcombe, E. Johnson, J. Martin, N. Brandon, A. Hawkes. A Greener Gas Grid: What are the Options? in: Sustainable Gas Institute, (Ed.). White Paper Series. Imperial College London, London, 2017. pp. 1-132.

[101] P. Balcombe, J. Speirs, E. Johnson, J. Martin, N. Brandon, A. Hawkes. The carbon credentials of hydrogen gas networks and supply chains. Renewable and Sustainable Energy Reviews. 91 (2018) 1077-88.

[102] C. Machens. Emission-Free Hydrogen For Shipping. Ship-technology.com, Marine Hydrogen and Fuel Cell Association (MHFCA)2017.

[103] Y.M.A. Welaya, M.M. El Gohary, N.R. Ammar. A comparison between fuel cells and other alternatives for marine electric power generation. International Journal of Naval Architecture and Ocean Engineering. 3 (2011) 141-9.

[104] T. Tronstad, H.H. Åstrand, G.P. Haugom, L. Langfeldt. Study on the use of fuell cells in shipping. in: D.G. Maritime, (Ed.). EMSA European Maritime Safety Agency, Hamburg, Germany, 2017. pp. 1-108.

[105] Ship Technology. Viking Lady Offshore Supply Vessel. 2010.

1310 [106] P. Pospiech. World's first fuel-cell ship FCS Alsterwasser proves its reliability. 2012.

[107] Y. Bicer, I. Dincer. Clean fuel options with hydrogen for sea transportation: A life cycle approach. International Journal of Hydrogen Energy. 43 (2018) 1179-93.

[108] ITF, OECD. Decarbonising Maritime Transport - Pathways to zero-carbon shipping by 2035. International Transport Forum, 2018. 

Angeles, US, 2017.

[110] S. Crolius. Ammonia-Powered Internal Combustion Engines. Ammonia Energy, 2016.

[111] C. Raucci, J. Calleya, S. Suarez De La Fuente, R. Pawling. Hydrogen on Board Ship: A First Analysis of Key Parameters and Implications. Marine Research Group. Bartlett Energy Institute, University College London, London, 2014.

[112] I. Staffell. The Energy and Fuel Data Sheet. 2011.

[113] Australian Maritime Safety Authority. Australia and Japan develop safety standards for shipping liquid hydrogen. 2017.

[114] D. Sadler, A. Cargill, M. Crowther, A. Rennie, J. Watt, S. Burton, et al. H21 - Leeds City Gate. Leeds City Gate, Northern Gas Networks, Wales and West Utilities, 2016.

[115] O. Schmidt, A. Gambhir, I. Staffell, A. Hawkes, J. Nelson, S. Few. Future cost and performance of water electrolysis: An expert elicitation study. International Journal of Hydrogen Energy 42 (2017) 30470-92.

[116] J. Speirs, P. Balcombe, E. Johnson, J. Martin, N. Brandon, A. Hawkes. A greener gas 1330 grid: What are the options. Energy Policy. 118 (2018) 291-7.

[117] A.E. Farrell, D.W. Keith, J.J. Corbett. A strategy for introducing hydrogen into transportation. Energy and Resources Group Energy Policy. 31 (2003) 1357-67.

[118] F. Vogler, D.G. Würsig. Fuel Cell Systems in Maritime Applications - Challenges, Chances and Experiences. ZemShips Final Conference ed. Germanischer Lloyd AG, Hamburg,

[119] S. Norwegian Electric. Another Ferry Contract for NES. 2017.

[120] O. Schmidt, A. Hawkes, A. Gambhir, I. Staffell. The future cost of electrical energy storage based on experience rates. Nature Energy. 2 (2017) 17110.

[121] G.M. Moore, C.A. Banuelos, T.T. Gray. Replacing Highly-Enriched Uranium in Naval Reactors. NTI, March. (2016).

[122] A. Petrovich. The imperatives of development of the Northern Sea Route in the XXI century. oko-planet.su.2013.

[123] J. Pike. Project 10081 Sevmorput. Global Security, 2018.

[124] A. International Atomic Energy. Advances in Small Modular Reactor Technology

1345 Developments. IAEA Advanced Reactors Information System (ARIS), Vienna International Centre, Austria, 2014.

[125] S.E. Hirdaris, Y.F. Cheng, P. Shallcross, J. Bonafoux, D. Carlson, B. Prince, et al. Considerations on the potential use of Nuclear Small Modular Reactor (SMR) technology for merchant marine propulsion. Ocean Engineering. 79 (2014) 101-30.

1350 [126] J. Fingas. Russia debuts largest ever nuclear icebreaker. 2016.

[127] W.M. Arkin, J. Handler. Naval Accidents, 1945-1988. Neptune Papers, Neptune Paper No 3 Washington: Greenpeace, Institute for Policy Studies. (1989).

[128] Royal Academy of Engineering. Future Ship Powering Options - Exploring alternative methods of ship propulsion. 2013.

1355 [129] I. Staffell, S. Pfenninger. Using bias-corrected reanalysis to simulate current and future wind power output. Energy. 114 (2016) 1224-39.

[130] S.E. Hirdaris, C.Y. F. The Role of Technology in Green Ship Design. 11th International Marine Design Conference, Glasgow, UK, 2012.

[131] T. Smith, P. Newton, G. Winn, A.G.L. Rosa. Analysis techniques for evaluating the fuel savings associated with wind assistance. Low Carbon Shipping Conference, London, UK, 2013. pp. 1-13. 
[132] T. Smith, C. Raucci, S.H. Hosseinloo, I. Rojon, J. Calleya, S.S.D.L. Fuente, et al. $\mathrm{CO}_{2}$ emissions from international shipping. Possible reduction targets and their associated pathways. 2016.

1365 [133] M. Traut, P. Gilbert, C. Walsh, A. Bows, A. Filippone, P. Stansby, et al. Propulsive power contribution of a kite and a Flettner rotor on selected shipping routes. Applied Energy. 113 (2014) 362-72.

[134] IWSA. IWSA Member - eConowind BV. The International Windship Association, 2018.

[135] FathomShipping. Could Wind Power Return To Commercial Shipping? gCaptain, 2012.

[136] N. Rehmatulla, S. Parker, T. Smith, V. Stulgis. Wind technologies: Opportunities and barriers to a low carbon shipping industry. Marine Policy. 75 (2017) 217-26.

[137] VPO Global. Eco Marine Power and Teramoto Iron works sign patent license agreement for energy-saving propulsion solutions. 2018.

[138] S. Pfenninger, I. Staffell. Long-term patterns of European PV output using 30 years of validated hourly reanalysis and satellite data. Energy. 114 (2016) 1251-65.

[139] M. Maloni, J.A. Paul, D.M. Gligor. Slow steaming impacts on ocean carriers and shippers. Maritime Economics \& Logistics. 15 (2013) 151-71.

[140] C.-Y. Lee, H.L. Lee, J. Zhang. The impact of slow ocean steaming on delivery reliability and fuel consumption. Transportation Research Part E: Transport and Environment. 76 (2015) 176-90.

[141] S. Mander. Slow steaming and a new dawn for wind propulsion: A multi-level analysis of two low carbon shipping transitions. Marine Policy. 75 (2017) 210-6.

[142] T. Tezdogan, A. Incecik, O. Turan, P. Kellett. Assessing the impact of a slow steaming approach on reducing the fuel consumption of a containership advancing in head seas. Transportation Research Procedia. 14 (2016) 1659-16668.

[143] J. Faber, D. Nelissen, G. Hon, H. Wang, M. Tsimplis. Regulated Slow Steaming in Maritime Transport: An Assessment of Options, Costs and Benefits. CE Delft, Delft, The Netherlands, 2012. pp. 1-117.

[144] P. Cariou. Is slow steaming a sustainable means of reducing CO 2 emissions from 1390 container shipping? Transportation Research Part D: Transport and Environment. 16 (2011) 260-4.

[145] World Shipping Counsil. Carbon Emissions. 2017.

[146] C. Ma, F. von Hippel. Ending the Production of Highly Enriched Uranium for Naval Reactors. The Nonproliferation Review. 8 (2008) 86-101.

1395 [147] P. Cariou, A. Cheaitou. The effectiveness of a European speed limit versus an international bunker-levy to reduce $\mathrm{CO} 2$ emissions from container shipping. Transportation Research Part D: Transport and Environment. 17 (2012) 116-23.

[148] N. Rehmatulla, J. Calleya, T. Smith. The implementation of technical energy efficiency and $\mathrm{CO} 2$ emission reduction measures in shipping. Ocean Engineering. 139 (2017) 184-97.

1400 [149] E. Almeida, T.C. Diamantino, O. de Sousa. Marine paints: The particular case of antifouling paints. Progress in Organic Coatings. 59 (2007) 2-20.

[150] D. Carteau, K. Vallée-Réhel, I. Linossier, F. Quiniou, R. Davy, C. Compère, et al. Development of environmentally friendly antifouling paints using biodegradable polymer and lower toxic substances. Progress in Organic Coatings. 77 (2014) 485-93.

1405 [151] M.S. Selim, M.A. Shenashen, S.A. El-Safty, S.A. Higazy, M.M. Selim, H. Isago, et al. Recent progress in marine foul-release polymeric nanocomposite coatings. Progress in Materials Science. 87 (2017) 1-32. 
[152] T. Smith, E. O'Keeffe, L. Aldous, P. Agnolucci. Assessment of Shipping's Efficiency Using Satellite AIS data. (2013).

1410 [153] J. Willsher. The Effect of Biocide Free Foul Release Systems on Vessel Performance International Paint Ltd, London, 2008.

[154] J.A. Fernandes, L. Santos, T. Vance, T. Fileman, D. Smith, J.D.D. Bishop, et al. Costs and benefits to European shipping of ballast water and hull-fouling treatment: Impacts of native and non-indigenous species. Marine Policy. 64 (2016) 148-55.

1415 [155] IMO. Anti-fouling systems. 2003.

[156] B.-G. Paik, K.-Y. Kim, S.-R. Cho, J.-W. Ahn, S.-R. Cho. Investigation on drag performance of anti-fouling painted flat plates in a cavitation tunnel. Ocean Engineering. 101 (2015) 26474.

[157] G. Swain. The importance of ship hull coatings and maintenance as drivers for environmental sustainability. Quarterly Journal of Ship Hull Performance. 1 (2011) 50-8.

[158] E. Harrould-Kolieb, J. Savitz. Shipping Solutions: Technological and Operational Methods Available to Reduce CO2. 2010.

[159] K. Senary, A. Tawfik, E. Hegazy, A. Ali. Development of a waste heat recovery system onboard LNG carrier to meet IMO regulations. Alexandria Engineering Journal. 55 (2016) 1951-60.

[160] D.V. Singh, E. Pedersen. A review of waste heat recovery technologies for maritime applications. Energy Conversion and Management. 111 (2016) 315-28.

[161] M.-H. Yang, R.-H. Yeh. Thermodynamic and economic performances optimization of an organic Rankine cycle system utilizing exhaust gas of a large marine diesel engine.

1430 Applied Energy. 149 (2015) 1-12.

[162] F. Baldi, C. Gabrielii. A feasibility analysis of waste heat recovery systems for marine applications. Energy. 80 (2015) 654-65.

[163] C. Sprouse, C. Depcik. Review of organic Rankine cycles for internal combustion engine exhaust waste heat recovery. Applied Thermal Engineering. 51 (2013) 711-22.

1435 [164] G. Theotokatos, G. Livanos. Techno-economical analysis of single pressure exhaust gas waste heat recovery systems in marine propulsion plants. Proceedings of the Institution of Mechanical Engineers, Part M: Journal of Engineering for the Maritime Environment. 227 (2013) 83-97.

[165] G.A. Livanos, G. Theotokatos, D.-N. Pagonis. Techno-economic investigation of

1440 alternative propulsion plants for Ferries and RoRo ships. Energy Conversion and Management. 79 (2014) 640-51.

[166] Z. Ma, D. Yang, Q. Guo. Conceptual design and performance analysis of an exhaust gas waste heat recovery system for a 10000TEU container ship. Polish Maritime Research. 19 (2012) 31-8.

1445 [167] R. Hutter, L. De Libero, P. Elbert, C.H. Onder. Catalytic methane oxidation in the exhaust gas aftertreatment of a lean-burn natural gas engine. Chemical Engineering Journal. 349 (2018) 156-67.

[168] J. Kamieniak, P.J. Kelly, C.E. Banks, A.M. Doyle. Methane emission management in a dual-fuel engine exhaust using Pd and Ni hydroxyapatite catalysts. Fuel. 208 (2017) 314-20.

1450 [169] D.J. Worth, M.E.J. Stettler, P. Dickinson, K. Hegarty, A.M. Boies. Characterization and Evaluation of Methane Oxidation Catalysts for Dual-Fuel Diesel and Natural Gas Engines. Emission Control Science and Technology. 2 (2016) 204-14.

[170] B. Sweeney. Shipping CO2 emissions can be eliminated by Calix RECAST system. . Energy Systems Conference London, UK, 2018. 
1455 [171] G.H. Rau, K. Caldeira. Enhanced carbonate dissolution:: a means of sequestering waste CO2 as ocean bicarbonate. Energy Conversion and Management. 40 (1999) 1803-13.

[172] G.H. Rau. CO2 Mitigation via Capture and Chemical Conversion in Seawater. Environmental Science \& Technology. 45 (2011) 1088-92.

[173] R.M. Cuéllar-Franca, A. Azapagic. Carbon capture, storage and utilisation technologies: A critical analysis and comparison of their life cycle environmental impacts. Journal of $\mathrm{CO} 2$ Utilization. 9 (2015) 82-102.

[174] Project LEILAC. Low Emission Intensity Lime and Cement project: FEED summary report. 2017.

[175] RAEng. Greenhouse gas removal. Royal Academy of Engineering, London, UK, 2018. 1465 pp. 1-136.

[176] DNV GL. Low carbon shipping towards 2050. 2017.

[177] Wisdom Events. Bio-LNG to Overtake Traditional LNG? 2017.

[178] I.A.G. Wilson, I. Staffell. Rapid fuel switching from coal to natural gas through effective carbon pricing. Nature Energy. 3 (2018) 365-72.

$1470 \quad$ [179] W.S. Council. World Port Rankings. 2015.

[180] C. Walsh, S. Mander, A. Larkin. Charting a low carbon future for shipping: A UK perspective. Marine Policy. 82 (2017) 32-40.

[181] Z. Wan, A. el Makhloufi, Y. Chen, J.Y. Tang. Decarbonizing the international shipping industry: Solutions and policy recommendations. Marine Pollution Bulletin. 126 (2018) 428-

[182] R. Halim, L. Kirstein, O. Merk, L. Martinez. Decarbonization Pathways for International Maritime Transport: A Model-Based Policy Impact Assessment. Sustainability. 10 (2018) 2243.

[183] D. Harrison, D. Radov, J. Patchett. Evaluation of the feasibility of alternative market1480 based mechanisms to promote low-emission shipping in European Union sea areas NERA Economic Consulting, London, 2004.

[184] R. Mcllveen, D. Helm, S. Less. Greener, Cheaper. Policy Exchange, London, 2010.

[185] J. Reinaud. Issues behind competitiveness and carbon leakage. Focus on Heavy Industry Paris: IEA IEA Information Paper. 2 (2008).

[186] S. Ribeiro-Kahn, S. Kobayashi, M. Beuthe, J. Gasca, D. Greene, D. Lee, et al. Transport and its infrastructure. IPCC Fourth Assessment Report: Working Group III Report "Mitigation of Climate Change". Intergovernmental Panel on Climate Change, 2007.

[187] M. Despines, S. Bullock, M. Childs, T. Picken. A dangerous distraction: why offsets are a mistake the U.S. cannot afford to make. Friends of the Earth, Washington, 2009.

1490 [188] J. David Harrison, PhD, D. Radov, J. Patchett, P. Klevnas, A. Lenkoski, P. Reschke, et al. Economic Instruments for Reducing Ship Emissions in the European Union NERA Consulting, European Commission DG Environment, London, 2005.

[189] H.N. Psaraftis, C.A. Kontovas. Balancing the economic and environmental performance of maritime transportation. Transportation Research Part D: Transport and Environment. 15 1495 (2010) 458-62.

[190] IMO. Reduction of GHG Emissions from Ships. International Maritime Organization, 2011.

[191] H.N. Psaraftis. Market-based measures for greenhouse gas emissions from ships: a review. WMU Journal of Maritime Affairs. 11 (2012) 211-32. 
1500 [192] M.-L. Song, Y. Guan, F. Song. Environmental efficiency, advances in environmental technology and total factor of environmental productivity of China. Kybernetes. 42 (2013) 943-54.

[193] M.M. Rahim, M.T. Islam, S. Kuruppu. Regulating global shipping corporations' accountability for reducing greenhouse gas emissions in the seas. Marine Policy. 69 (2016) 159-70.

[194] J. Moffat. Arranging deckchairs on the titanic: climate change, greenhouse gas emissions and international shipping. Australian and New Zealand Maritime Law Journal. 24 (2010) 104-25.

[195] A. Miola, M. Marra, B. Ciuffo. Designing a climate change policy for the international maritime transport sector: Market-based measures and technological options for global and regional policy actions. Energy Policy. 39 (2011) 5490-8.

[196] S. Brunner, C. Flachsland, G. Luderer, O. Edenhofer. Emissions Trading Systems: an overview. (2009).

[197] M. Nicolini, M. Tavoni. Are renewable energy subsidies effective? Evidence from Europe. Renewable and Sustainable Energy Reviews. 74 (2017) 412-23. 